\title{
A novel structure associated with aging is augmented in the DPP6-KO mouse brain
}

\author{
Lin Lin ${ }^{1 \dagger}$, Ronald S. Petralia ${ }^{2 \dagger}$, Ross Lake ${ }^{3}$, Ya-Xian Wang ${ }^{2}$ and Dax A. Hoffman ${ }^{1 *}$ (1)
}

\begin{abstract}
In addition to its role as an auxiliary subunit of A-type voltage-gated $\mathrm{K}^{+}$channels, we have previously reported that the single transmembrane protein Dipeptidyl Peptidase Like 6 (DPP6) impacts neuronal and synaptic development. DPP6-KO mice are impaired in hippocampal-dependent learning and memory and exhibit smaller brain size. Using immunofluorescence and electron microscopy, we report here a novel structure in hippocampal area CA1 that was significantly more prevalent in aging DPP6-KO mice compared to WT mice of the same age and that these structures were observed earlier in development in DPP6-KO mice. These novel structures appeared as clusters of large puncta that colocalized NeuN, synaptophysin, and chromogranin A. They also partially labeled for MAP2, and with synapsin-1 and VGluT1 labeling on their periphery. Electron microscopy revealed that these structures are abnormal, enlarged presynaptic swellings filled with mainly fibrous material with occasional peripheral, presynaptic active zones forming synapses. Immunofluorescence imaging then showed that a number of markers for aging and especially Alzheimer's disease were found as higher levels in these novel structures in aging DPP6-KO mice compared to WT. Together these results indicate that aging DPP6-KO mice have increased numbers of novel, abnormal presynaptic structures associated with several markers of Alzheimer's disease.
\end{abstract}

Keywords: DPP6, Alzheimer's disease, Aging dementia, Presynaptic terminals

\section{Introduction}

DPP6 is a type II single pass transmembrane protein expressed in brain $[35,64]$, and well known as an auxiliary subunit of the $\mathrm{Kv} 4$ family of voltage-gated $\mathrm{K}^{+}$channels [45], which play a crucial role in neuronal excitability and plasticity $[23,65]$. We previously reported a surprising role for DPP6 in hippocampal synaptic development and function that is apparently independent of Kv4.2 [36, 37]. Clinically, the DPP6 gene has been associated with numerous intellectual and neurodevelopmental disorders [6, 17, 33, $41,43,47,53,55,56]$. An important recent study showed

\footnotetext{
${ }^{*}$ Correspondence: hoffmand@mail.nih.gov

${ }^{\dagger}$ Lin Lin and Ronald S. Petralia contributed equally to this work.

${ }^{1}$ Molecular Neurophysiology and Biophysics Section, Program in Developmental Neuroscience, Eunice Kennedy Shriver National Institute of Child Health and Human Development, 35 Lincoln Drive, MSC 3715, Building 35, Room 3C-905, Bethesda, MD 20892-3715, USA Full list of author information is available at the end of the article
}

DPP6 to be a novel gene in dementia, finding enhanced rare variants and nonsense, frameshift and missense mutations in early Alzheimer's disease (AD) and frontotemporal dementia patient cohorts [9]. Another finding by Zelaya et al. [77] demonstrated an olfactory progressive proteome modulation in $\mathrm{AD}$, which shows olfactory dysfunction in up to $90 \%$ of patients. They report a specific late reduction of DPP6 in the olfactory bulb of patients with AD. Overall, these findings provided basic information for understanding possible roles of DPP6 in aging and the pathophysiology of diseases such as $\mathrm{AD} /$ dementia.

$\mathrm{AD}$ is the most common form of major neurocognitive disorder (dementia). It is a progressive neurodegenerative disease associated with memory impairment and cognitive decline. Currently, definitive diagnoses of $\mathrm{AD}$ require post-mortem analysis and there are no curative therapies for AD $[7,10,57]$. Diagnostic hallmarks include the abnormal accumulation of extracellular amyloid- $\beta$ original author(s) and the source, provide a link to the Creative Commons licence, and indicate if changes were made. The images or other third party material in this article are included in the article's Creative Commons licence, unless indicated otherwise in a credit line to the material. If material is not included in the article's Creative Commons licence and your intended use is not permitted by statutory regulation or exceeds the permitted use, you will need to obtain permission directly from the copyright holder. To view a copy of this licence, visit http://creativecommons.org/licenses/by/4.0/. The Creative Commons Public Domain Dedication waiver (http://creativeco mmons.org/publicdomain/zero/1.0/) applies to the data made available in this article, unless otherwise stated in a credit line to the data. 
peptide ( $\mathrm{A} \beta$, amyloid plaques), intracellular neurofibrillary tangles composed of phosphorylated tau (pTau), and neuronal loss. These abnormalities that characterize AD are particularly prevalent in the hippocampus such that "hippocampal atrophy is one of the earliest detectable symptoms of ongoing neurodegeneration" [42]. A $\beta$ and pTau pathologies are associated with neuroinflammation characterized by activation of microglia and astrocytes and elevated levels of proinflammatory cytokines [50,60].

In both human patients with early $\mathrm{AD}$ and in mouse models of $\mathrm{AD}, \mathrm{A} \beta$ accumulation precedes and promotes tau pathology. In human brains with early $A D$, intraneuronal $A \beta 42$ accumulation in hippocampal cell bodies precedes hyperphosphorylation of tau $[20,21]$, and in a common mouse model of AD (3xTg-AD mouse), intraneuronal $A \beta$ accumulation in cell bodies also precedes tau hyperphosphorylation [48, 49]. Microglia activation and proliferation around amyloid plaques is also a key feature in $\mathrm{AD}$ pathogenesis.

Tau proteins stabilize microtubules and play a role in axonal transport and neurite outgrowth $[4,5,11,63,66]$. These functions of tau can be modulated by phosphorylation that can be both physiological and pathological to the cell. There is significant evidence that a disruption of normal phosphorylation events results in tau dysfunction in neurodegenerative diseases such as $\mathrm{AD}$, and is a contributing factor to the pathogenic processes $[3,25]$. The resulting abnormal tau accumulation in $\mathrm{AD} /$ dementia may lead, for example, to various axonopathies such as axonal swellings $[38,70]$.

In this study, we examined the cell architecture and proteins associated with aging in the hippocampus of DPP6-KO mice, and discovered unique clusters of large NeuN-labelled puncta concentrated throughout the hippocampal CA1 region that were larger and more abundant and expressed at earlier ages in DPP6-KO mice compared to WT. These structures partly colocalized with a number of proteins associated with $A D$, including $A \beta$, pTau, $\alpha$-synuclein and chromogranin A. Labeling for a number of markers of $\mathrm{AD}$ was higher in the puncta of the DPP6$\mathrm{KO}$ compared to WT, including $\mathrm{A} \beta$, pTau, $\alpha$-synuclein, and APP. Immunocytochemical and ultrastructural methods showed that these structures are derived from abnormal swollen presynaptic terminals and are associated with postsynaptic dendrites and synapses. We also found immunocytochemical and biochemical evidence for substantial gliosis. Our findings demonstrate that DPP6, in addition to its effects on early synapse development appears to be important for the maintenance of synaptic function during aging as its loss leads to an increase in abnormal synaptic structures associated with physical and biochemical markers for dementia.

\section{Materials and methods \\ Animals}

DPP6-KO and WT mice were weaned at 3 weeks of age, genotyped via PCR, and housed 3-4 mice per cage. Mice were housed under a 12-h light/dark cycle with the lights off at 18:00. We only used male mice in all experiments. DPP6KO mice were originally from Dr. B. Rudy at NYU School of Medicine, New York, and WT C57BL/6 were originally from Jackson Laboratory. All animal procedures were performed in accordance with guidelines approved by the National Institute of Child Health and Human Development Animal Care and Use Committee and in accordance with NIH guidelines.

\section{Electron microscopy}

Hippocampi were prepared for transmission electron microscope (TEM) study as described previously [32]. Briefly, WT and DPP6-KO, 12-month old mice were fixed in $4 \%$ paraformaldehyde plus $2 \%$ glutaraldehyde (Electron Microscopy Sciences (Hatfield, PA; EMS) in phosphate buffer $(\mathrm{PB})$, then washed in $\mathrm{PB}$ and vibratomed at $150 \mu \mathrm{m}$. Slices were washed in cacodylate buffer and placed in $1 \%$ osmium tetroxide in cacodylate buffer, washed again in cacodylate buffer, and dehydrated in an ethanol series with $1 \%$ uranyl acetate added to the $50 \%$ ethanol. Tissue was placed in propylene oxide (PO), and then in an epon/PO mix and finally in pure epon; then samples were embedded and hardened in an oven at $64{ }^{\circ} \mathrm{C}$. Thin sections $(60 \mathrm{~nm})$ were placed on single slot, formvar/carbon coated nickel grids (EMS), stained with uranyl acetate and lead citrate, and examined in a JEOL JEM2100 TEM (Peabody, MA). Images were taken from $2 \mathrm{WT}$ and $2 \mathrm{KO}$ mice, in all areas of the CA1, as well as in the molecular layer of the dentate gyrus.

Mouse hippocampi used for postembedding immunogold localization were prepared as described previously [22, 36, 52, 65]. Briefly, WT and DPP6-KO, 12-month old mice were perfused with phosphate buffer, followed by perfusion with $4 \%$ paraformaldehyde $+0.5 \%$ glutaraldehyde in phosphate buffer. Fixed brains were vibratomed at $350 \mu \mathrm{m}$, then cryoprotected in glycerol overnight, frozen in a Leica EM CPC (Vienna, Austria), and processed and embedded in Lowicryl HM-20 resin in a Leica AFS freeze-substitution instrument. Thin sections were incubated in $0.1 \%$ sodium borohydride $+50 \mathrm{mM}$ glycine in Tris-buffered saline plus $0.1 \%$ Triton X-100 (TBST). Sections were immersed in $10 \%$ normal goat serum (NGS) in TBST, and primary antibody in $1 \%$ NGS/TBST 
(overnight), then incubated with immunogold-conjugated secondary antibodies (Ted Pella, Redding, CA, USA) in $1 \%$ NGS in TBST with $0.5 \%$ polyethylene glycol $(20,000 \mathrm{MW})$, and stained with uranyl acetate and lead citrate. For double-immunogold labeling, the 2 primary antibodies were incubated together, and also the 2 secondary immunogold antibodies were incubated together.

Two mice each from WT and DPP6-KO were studied for NeuN (1:50, rabbit, MilliporeSigma) and NeuN (1:501:100, mouse, Millipore) antibodies, and for antibodies to MAP2 (1:100, mouse, Millipore), synaptophysin (1:7-1:10, mouse, Sigma), APP (1:25, rabbit, Abcam), and A $\beta$-amyloid (1:25-1:50, rabbit, MilliporeSigma). NeuN immunogold labeling was studied in either single labeling or double labeling with synaptophysin or MAP2; the latter 2 antibodies were studied only in the double labeling. The mouse NeuN immunogold labeling (1/100 and $15 \mathrm{~nm}$ gold) shown in Fig. 1 was taken from a double labeling study with rabbit GFAP (1/200 and $5 \mathrm{~nm}$ gold), which labeled mainly the glial cell somas and associated large processes (data not shown). Additional immunogold studies with antibodies to AT8 (1:25, mouse, Thermo Fisher), A $\beta$ amyloid (1:50, mouse, BioLegend) and another synaptophysin (1:7, SP15, mouse, MilliporeSigma) produced only rare (background) gold labeling and thus were controls for the immunogold technique. Most successful immunogold labeling studies concentrated on the $\mathrm{NeuN}^{+}$swellings, which were difficult to find due to their scattered distribution and required extensive searching on the EM sections.

\section{Immunofluorescence and immunohistochemistry}

Anesthetized mice were perfused with PBS buffer and then with $4 \%$ paraformaldehyde (PFA) in PBS. The collected brains were placed in 4\% PFA for $24 \mathrm{~h}$ and then equilibrated in $30 \%$ sucrose for $24 \mathrm{~h}$. A series of equidistant floating $30 \mu \mathrm{m}$ or frozen $7 \mu \mathrm{m}$ coronal sections were prepared. First, sections were incubated in blocking buffer (10\% Normal goat serum and $0.3 \%$ Triton X-100 in PBS) for 30 min at RT. Thereafter, samples were incubated overnight with the primary antibody at $4{ }^{\circ} \mathrm{C}$ and then were incubated with the appropriate fluorescent probe-conjugated secondary antibodies for $1 \mathrm{~h}$ at RT. Nuclei were counterstained with DAPI. Immunofluorescence-labelled slides were imaged using either a Zeiss 710 or 880 confocal microscope; or the entire brain section or hippocampus was scanned using a Carl Zeiss AxioScan. Z1 slide scanner with a $20 \times$ objective (Plan-Apochromat, NA 0.8 ) and a Colibri7 LED illumination source. We used ImageJ for IF quantification with blinded images.

\section{Antibodies}

\begin{tabular}{|c|c|c|c|c|}
\hline Name & Species & Company & Catalog\# & IHC \\
\hline $\begin{array}{l}\text { Amyloid Precur- } \\
\text { sor Protein }\end{array}$ & Rabbit & Abcam & ab32136 & $1: 500$ \\
\hline $\begin{array}{l}\text { beta-Amyloid } \\
1-16\end{array}$ & Mouse & BioLegend & 803001 & $1: 1000$ \\
\hline $\begin{array}{l}\text { beta-Amyloid } \\
1-42\end{array}$ & Rabbit & MilliporeSigma & Ab5078P & $1: 400$ \\
\hline alpha-Synuclein & Rabbit & Novus & NBP2-15365 & $1: 400$ \\
\hline Chromogranin A & Rabbit & Novus & NB120-15160SS & $1: 500$ \\
\hline GAD67 & Mouse & Abcam & ab26116 & $1: 2000$ \\
\hline GFAP & Mouse & Chemicon & MB360 & $1: 1000$ \\
\hline GFAP & Rabbit & DAKO & Z033429-2 & $1: 2000$ \\
\hline Iba1 (ICC IHC) & Rabbit & Wako & 019-19741 & $1: 800$ \\
\hline MAP-2 & Mouse & Millipore & MAB-3418 & $1: 500$ \\
\hline MAP-2 & Rabbit & Millipore & Ab-5622 & $1: 500$ \\
\hline NeuN & Mouse & Millipore & MAB377 & $1: 1000$ \\
\hline NeuN & Rabbit & MilliporeSigma & ABN78 & $1: 500$ \\
\hline Synapsin I & Rabbit & Novus & NB300-104 & $1: 200$ \\
\hline Synaptophysin & Mouse & Sigma & S-5768 & $1: 500$ \\
\hline $\begin{array}{l}\text { PHF-Tau at } \\
\text { Thr231 (AT180) }\end{array}$ & Mouse & Thermo Fisher & MN1040 & $1: 200$ \\
\hline Ubiquitin & mouse & Abcam & AB7254 & $1: 1000$ \\
\hline VGLUT1 & Guinea pig & Millipore & AB5905 & $1: 500$ \\
\hline
\end{tabular}

Imaging and statistical analyses

We used ImageJ to measure the intensity of each NeuN+large punctum. First, we outlined the punctum based on the NeuN + labeling; then, we switched to the other marker channel to use the same punctum shape to measure the mean intensity and surface area. The $n$ values and details of controls and comparisons used for statistical analyses are described for each experiment in the corresponding figure legends section. Statistical analyses were performed using GraphPad Prism 8. We used oneway or two-way ANOVA and Student's $t$ test. All results are presented as the mean \pm SEM. 


\section{A}

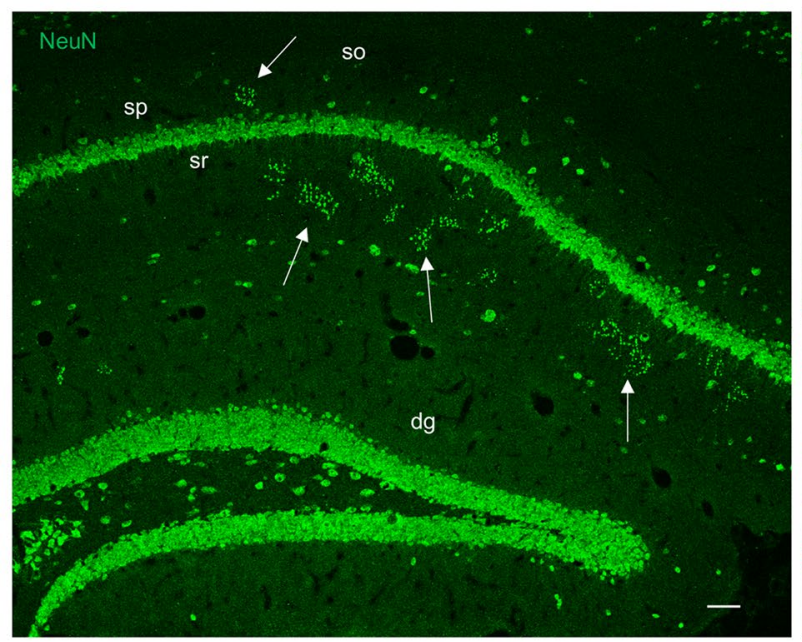

D

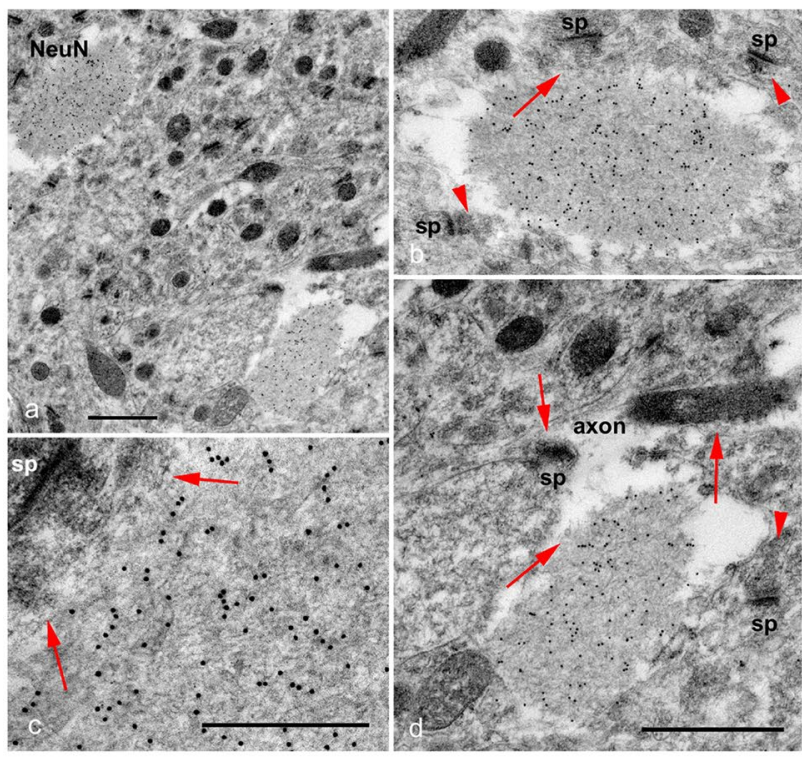

B
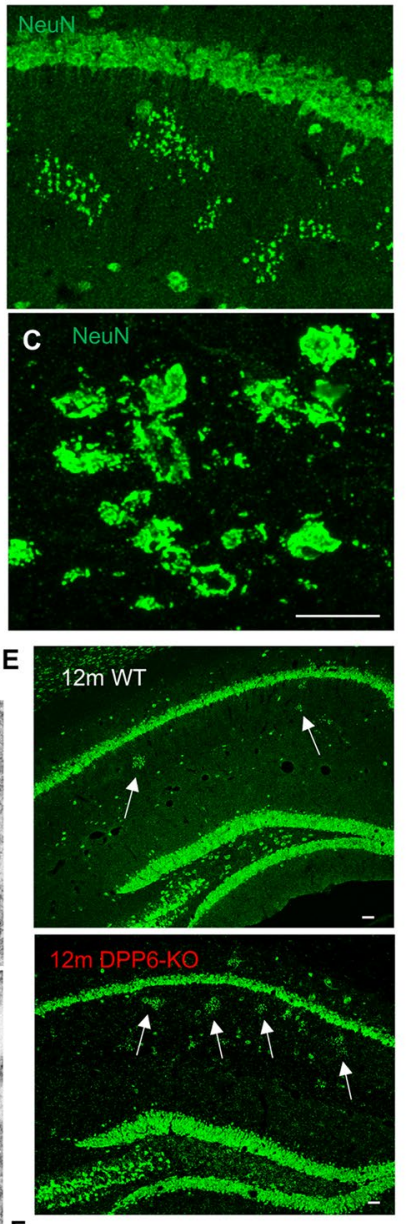

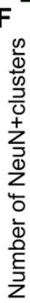

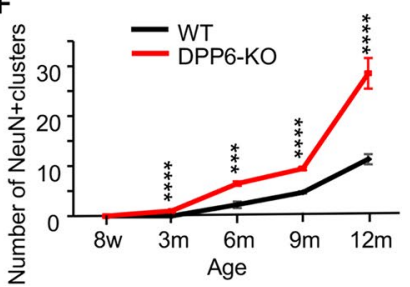

Fig. 1 Novel large clusters of $\mathrm{NeuN}^{+}$puncta/swellings are found in the hippocampus of DPP6-KO mice. $\mathbf{A}$ In the CA1 region of the hippocampus of 12-month old DPP6-KO brain sections, immunofluorescence labeling for NeuN (green, 1:500, Millipore) is concentrated not only in the neuronal somas but also in novel structures made of enlarged, variable puncta formed in clusters (arrows). Scale bar $=100 \mu \mathrm{m}$, dg, dentate gyrus; so, stratum oriens; sp, stratum pyramidale; sr, stratum radiatum. B A higher magnification image of one of the clusters shown in $\mathbf{A}$. C Even higher magnification of a single cluster from another section. Scale bar $=5 \mu \mathrm{m}$. D Immunogold labeling of NeuN (15 nm) in the CA1 stratum radiatum of the hippocampus of a WT 12-month old mouse. Da is a low magnification including two $\mathrm{NeuN}^{+}$swellings. The top swelling is shown in higher magnification in $\mathbf{D b}, \mathbf{c}$ and the bottom swelling is shown in Dd. Note how the immunogold labeling is concentrated mainly in the two adjacent swellings, which show a fibrous interior and traces of presynaptic vesicles (active zone; arrows) on the periphery, associated with postsynaptic spines (sp). The structure of these vesicles resembles those seen in adjacent separate presynaptic terminals (arrowheads); in $\mathbf{D b}$, the cluster of presynaptic vesicles in the lower left (arrowhead) probably is a presynaptic zone of the swelling also, but the connection is not distinct in the image. In $\mathbf{D d}$, the NeuN ${ }^{+}$swelling extends off of an axon with presynaptic vesicles that makes a synapse with a spine in the image. (Da, $\mathbf{d}$; the scale bar in $\mathbf{d}$ also applies to $\mathbf{b}$ ) or $500 \mathrm{~nm}$ in $\mathbf{D c}$. Compare to examples from a DPP6-KO mouse shown in the Additional file 1: Fig. S1. And compare the presynaptic active zones in the periphery of the swellings in Figs. 1D, 3, and Additional file 1: Fig. S1. EThese novel NeuN-labeled clusters are observed more in 12-month old DPP6-KO mice than in WT. Scale bar $=100 \mu \mathrm{m}$. F: Graph comparing the number of novel clusters in the CA1 region of the hippocampus during development from 8-week to 12-month old mice in WT and DPP6-KO mice. From 8-week to 12-month old, labeling in aged DPP6-KO mice is significantly increased compared to WT ( $\mathrm{n}=8-38$ images per age from 3 to 8 mice each WT and DPP6-KO. ${ }^{* * *}=p<0.001,{ }^{* * * *}=p<0.0001$ ) 
A

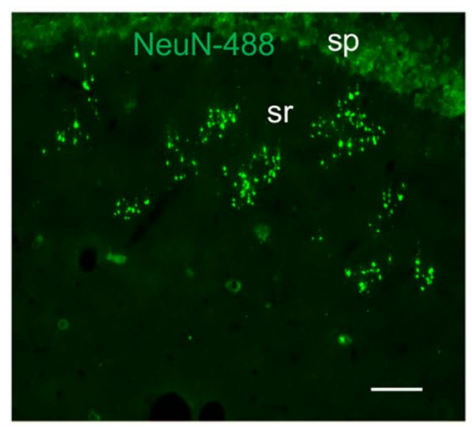

B

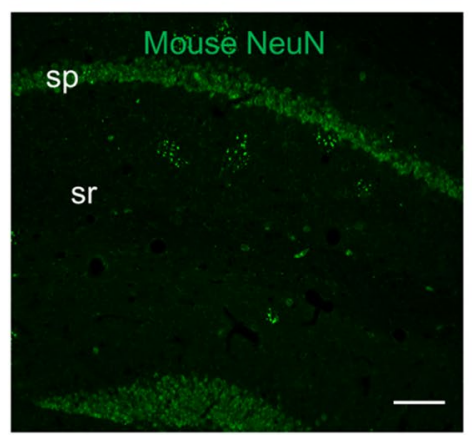

C

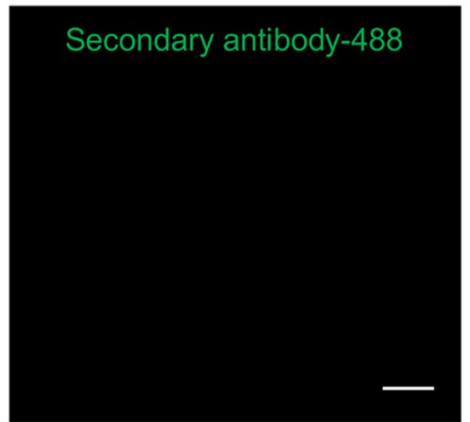

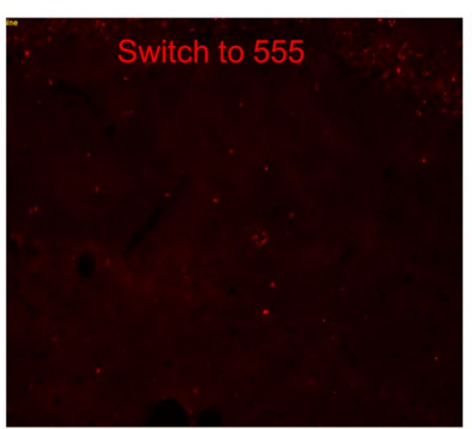
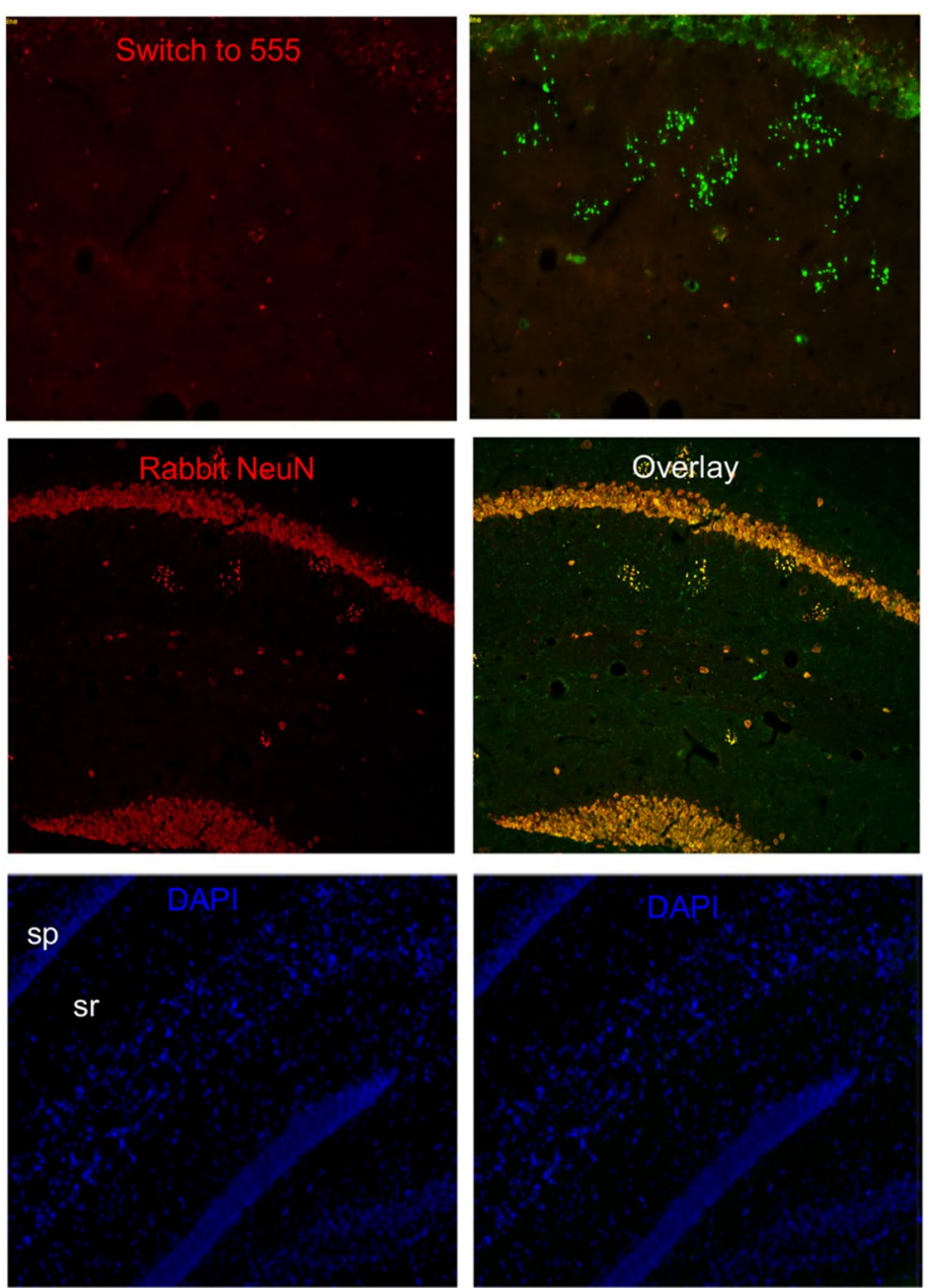

Fig. 2 Controls for immunofluorescence labeling. A IF labeling of $\mathrm{NeuN}^{+}$puncta with Alexa fluor-488 goat anti-Rabbit lgG secondary antibody (1:800, ThermoFisher). The NeuN labeled puncta only can be observed at 488, and not at 555, showing that the NeuN labeling is not caused by autofluorescence. B Double labeling showing the colocalization of NeuN mouse antibody (green) and rabbit antibody (red). Scale bar $=50 \mu \mathrm{m}$. C IF labeling only with Alexa fluor-488 goat anti-Rabbit IgG secondary antibody (1:800, ThermoFisher) control; without the primary NeuN antibody, the puncta cannot be observed. Scale bar $=50 \mu \mathrm{m}$. sp, stratum pyramidale; sr, stratum radiatum

\section{Results}

\section{A novel structure in aging mice develops earlier} and is more abundant in the DPP6-KO

During the performance of Immunofluorescence (IF) staining with NeuN antibody to characterize the neurons in the hippocampus, of 12-month DPP6-KO and corresponding WT mice, we noted clusters of large puncta with NeuN labeling in the CA1 region of DPP6-KO mice (Fig. 1A-C). NeuN is a neuron-specific RNA-binding protein, Rbfox3, with at least 2 subtypes including one $(46-\mathrm{kDa})$ that is mainly nuclear and another $(48-\mathrm{kDa})$ that is mainly cytoplasmic [14]. Most studies report cytoplasmic localization in neuron somas and some dendrites, but Luca et al. [40] also found axonal localization in the occipital cortex of humans with HIV-associated cognitive impairment. Subsequent electron microscope studies using immunogold labeling $(15 \mathrm{~nm})$ for NeuN in the CA1 stratum radiatum of the hippocampus revealed that the gold labeling was highly concentrated mainly in large swellings, with relatively few gold particles found in the surrounding neuropil (Fig. 1D). The images show immunogold labeling that was concentrated mainly in two adjacent swellings, which had fibrous interiors and traces of presynaptic vesicles (active zone; arrows) on the periphery, associated with postsynaptic spines (sp). Note especially Fig. 1Dd, in which the synaptic region of the swelling was seen extending from an axon. We further wondered when these novel structures form. We 
examined mice at 5 different age points in a range of ages from 8-weeks to 12 months for WT and DPP6-KO mouse hippocampi (Fig. 1E, F). In 8-week adult mice, we didn't find any novel $\mathrm{NeuN}^{+}$structures in either WT or DPP6-KO mice. A few of these were observed in 3-month old DPP6-KO mice but not in WT. Clusters increased up to 12 months of age in both DPP6-KO and WT mice although there were nearly threefold more found in DPP6-KO compare to WT (Fig. 1F, $p<0.0001$ ). Figure 1E shows an example of the labeling in 12-month old WT and DPP6-KO mice.

We confirmed that this NeuN labeling is not caused by autofluorescence (Fig. 2a) and it is consistent between two different mouse and rabbit species of NeuN antibodies (Fig. 2b). We also confirmed that this labeling is absent in sections stained with the control secondary antibody only (Fig. 2c).

\section{The novel structure shows characteristics of abnormal presynaptic terminals}

We then performed ultrastructural studies using transmission electron microscopy (TEM), and we documented novel, large swellings in the CA1 region of the 12-month DPP6-KO mice (Fig. 3). Thus, the large swellings seen with both ultrastructural and immunogold EM studies may represent the large $\mathrm{NeuN}^{+}$puncta seen with IF. The presence of high concentrations of NeuN, seen with both IF and EM, confirm that these structures are derived from neurons. Further, the structural evidence suggests that these swellings were formed from presynaptic terminals, represented in approximately 3 stages in the formation of the swellings. Stage $1-$ seen in Fig. 3a: In this example, the swelling shows central mitochondria (mito) and large clusters of presynaptic vesicles (arrows) including one cluster at an active zone on a spine synapse (sp). The cytoplasm is dense and full of thick fibrils. Stage 2-seen in Fig. 3b, c: Here the swelling is filled with thick fibrils but has very few presynaptic vesicles; a group (arrow) can be seen at an active zone of a spine synapse (sp). Presynaptic active zones also are seen in the periphery of some swellings labeled with immunogold for NeuN (Fig. 1D and Additional file 1: Fig. S1). In Fig. 1D, clusters of presynaptic vesicles (arrows in $1 \mathrm{D} b$ d) are found in the peripheral area of the swelling and form at an active zone with a postsynaptic spine (sp). Similar examples of presynaptic vesicles (p) at active zones in the swelling periphery and opposite postsynaptic spines (sp) are seen in Additional file 1: Fig. S1A,B. Also, by stage 2, organelles tend to be lost from the swelling; the remainders of dysmorphic mitochondria can be seen in the swelling in Additional file 1: Fig. S1C. Stage 3-Fig. 3d, f: Many other swellings are light with no evident presynaptic vesicles and with thin fibrils. In these
3 examples from the CA1 stratum oriens of a DPP6-KO mouse, the periphery of the swelling is very convoluted, and it extends thin processes around the surrounding synapses (similar in appearance to glial processes). However, in all 3 images, one of the processes from the swelling appears to be continuous with a terminal filled with presynaptic vesicles (arrows in Fig. 3d, f). Overall, these results suggest that the novel large clusters of $\mathrm{NeuN}^{+}$ puncta seen with IF are the large $\mathrm{NeuN}^{+}$swellings seen with EM.

We found complete colocalization within the clusters when we performed IF staining with NeuN and the presynaptic marker synaptophysin (Fig. 4a), confirming that the large $\mathrm{NeuN}^{+}$clusters are formed from presynaptic terminals. Similarly, EM immunogold labeling showed that $20 \mathrm{~nm}$ gold for NeuN is concentrated in the large swellings and colocalizes very well with $10 \mathrm{~nm}$ gold for synaptophysin (Fig. 4b; the arrows in the 2 high magnification images label all $10 \mathrm{~nm}$ gold particles to illustrate the reciprocal distribution of NeuN and synaptophysin throughout the center of the swelling). Both results suggest that the novel puncta are modified/derived from presynaptic terminals.

We also performed IF staining for the dendritically enriched marker MAP2. Images showed that MAP2 is only partly colocalized with NeuN clusters of puncta (Fig. 4c, d). Similarly, with $10 \mathrm{~nm}$ gold for MAP2, EM immunogold labeling showed partial colocalization with the $\mathrm{NeuN}^{+}$swellings, mainly in postsynaptic structures around the periphery of the swellings (Fig. 4e). IF images also showed that MAP2 and synaptophysin are partly colocalized in the puncta (Fig. 5a). In addition, several presynaptic terminal markers labeled some $\mathrm{NeuN}+$ puncta on the periphery of the $\mathrm{NeuN}^{+}$large puncta, including commonly VGluT1 and Synapsin-1 (Fig. 5b, c). But these $\mathrm{NeuN}^{+}$large puncta did not colocalize with antibodies to GAD67, a marker for GABAergic, inhibitory neuronal processes (Additional file 2: 2A). Interestingly, labeling for Kv4.2, a functional binding partner of DPP6, was lower in DPP6-KO NeuN + puncta compared to WT (Fig. 6e, j).

\section{The novel structure has markers of aging and/or AD}

We further characterized by IF the novel clusters with markers that are associated with aging and AD. The $\mathrm{NeuN}^{+}$puncta in the clusters were partially colocalized with A $\beta$, APP, $\alpha$-synuclein, and pTau (AT180; Fig. 6ad) and more fully colocalized with chromogranin A (Fig. 5d). Chromogranin A is a mediator between neuronal, glial and inflammatory mechanisms found in AD, and about $30 \%$ of $\beta$-amyloid plaques have been shown to co-label with chromogranin A [30]. Interestingly, labeling of the NeuN + puncta for A $\beta, A P P, \alpha$-synuclein, 


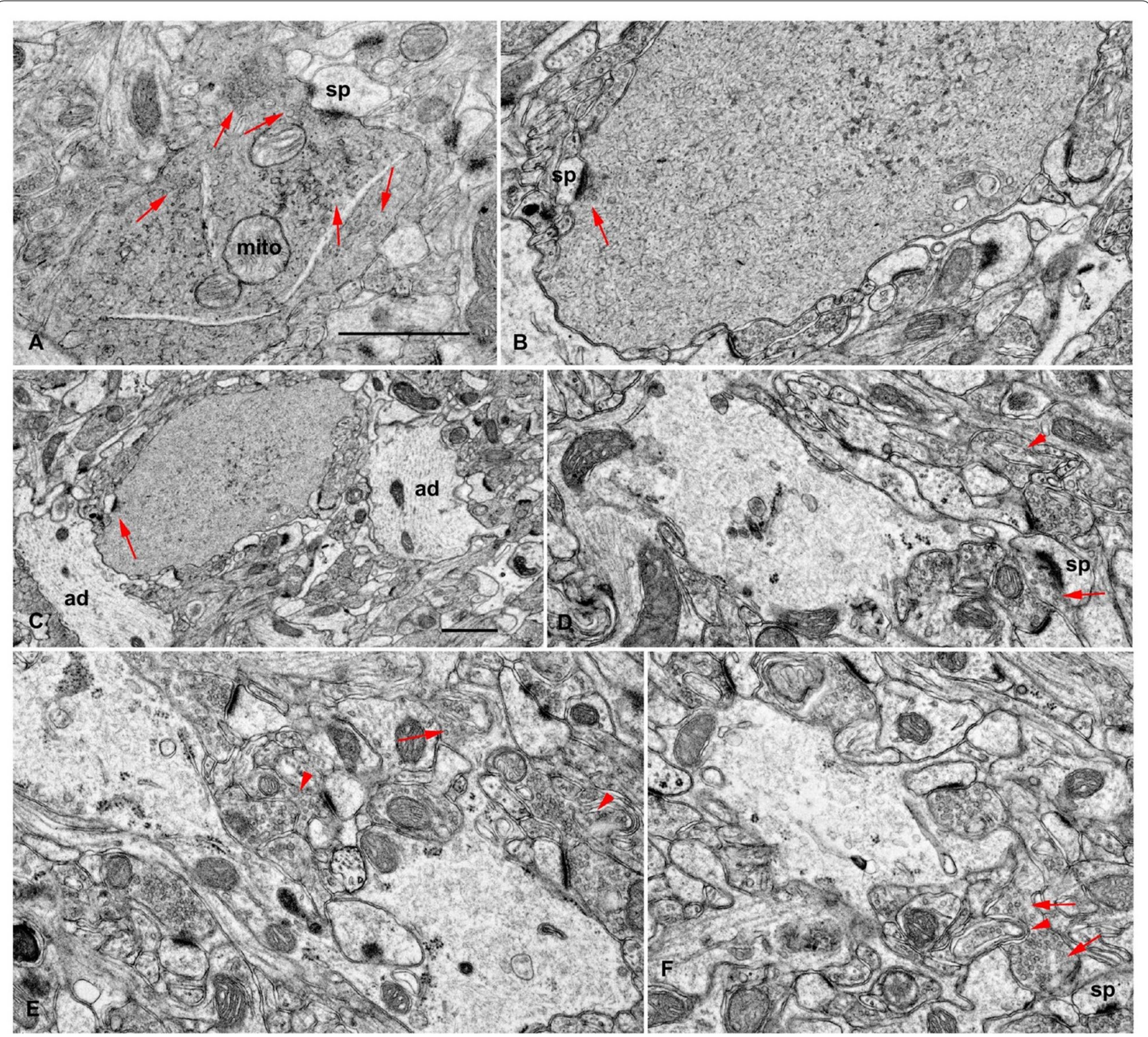

Fig. 3 Ultrastructural study of large swellings seen in the CA1 region of the hippocampus of 12-month-old mice These likely correspond to the large puncta found in the novel clusters labeled with immunofluorescence for NeuN (Fig. 1a-c). All appear to be derived from presynaptic terminals, and they may represent approximately 3 stages in the formation of the swellings. a Stage 1: The swelling in $\mathbf{A}$ shows central mitochondria (mito) and large clusters of presynaptic vesicles (arrows) including one cluster at an active zone on a spine synapse (sp). The cytoplasm is dense and full of thick fibrils. B, c Stage 2: The swelling in $\mathbf{B}$ and $\mathbf{c}$ is filled with thick fibrils but has very few presynaptic vesicles; a group (arrow) can be seen at an active zone of a spine synapse (sp). $\mathbf{A}-\mathbf{C}$ are from the $\mathrm{CA} 1$ stratum radiatum (A, KO; B, C, WT). D-F -Stage 3: Many of the swellings are light with no evident presynaptic vesicles and with thin fibrils. In these 3 examples from the CA1 stratum oriens of a DPP6-KO mouse, the periphery of the swelling is very convoluted, and it extends thin processes around the surrounding synapses (similar in appearance to glial processes). However, in all 3 images, one of the processes from the swelling appears to be continuous with a terminal filled with presynaptic vesicles (arrows). D-F also shows distinctive invaginating presynaptic terminals (arrowheads). Scale bars in $\mathbf{A}$ and $\mathbf{C}$ are $1 \mu \mathrm{m}$, and the one in $\mathbf{A}$ is for all other micrographs. ad, apical dendrite of pyramidal neuron

and AT180 was greater in the DPP6-KO compared to WT, and the labeling was concentrated in the peripheral region of the puncta (Fig. $6 \mathrm{f}-\mathrm{i}$ ). However, the puncta were not labeled for ubiquitin, a protein found commonly in amyloid plaques and neurofibrillary tangles in AD (Additional file 2: Fig. S2B). These novel puncta also were surrounded with activated astrocytes (Fig. 5e) and microglia (Fig. 5f). 
A
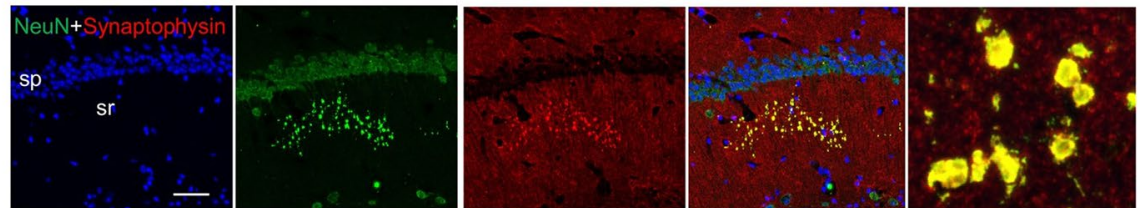

B.
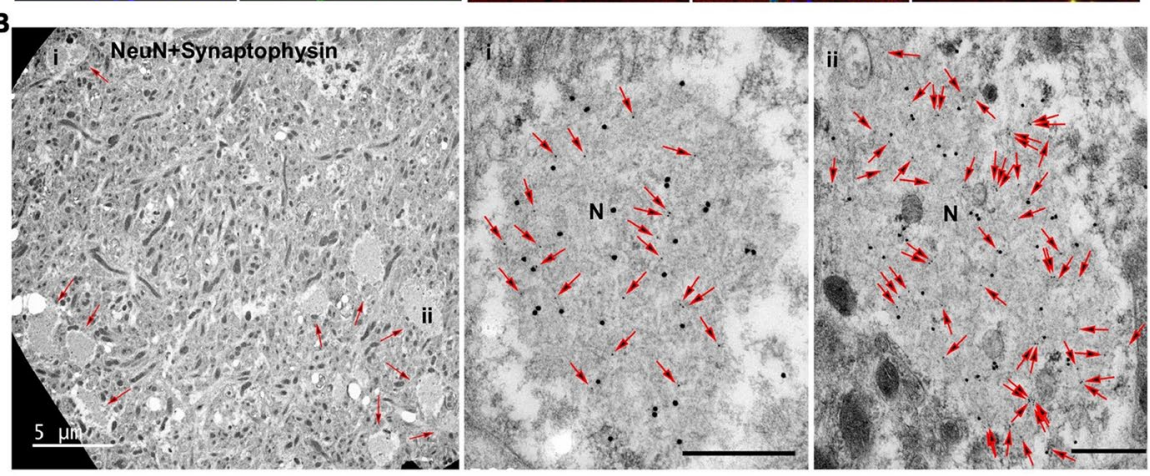

E

C
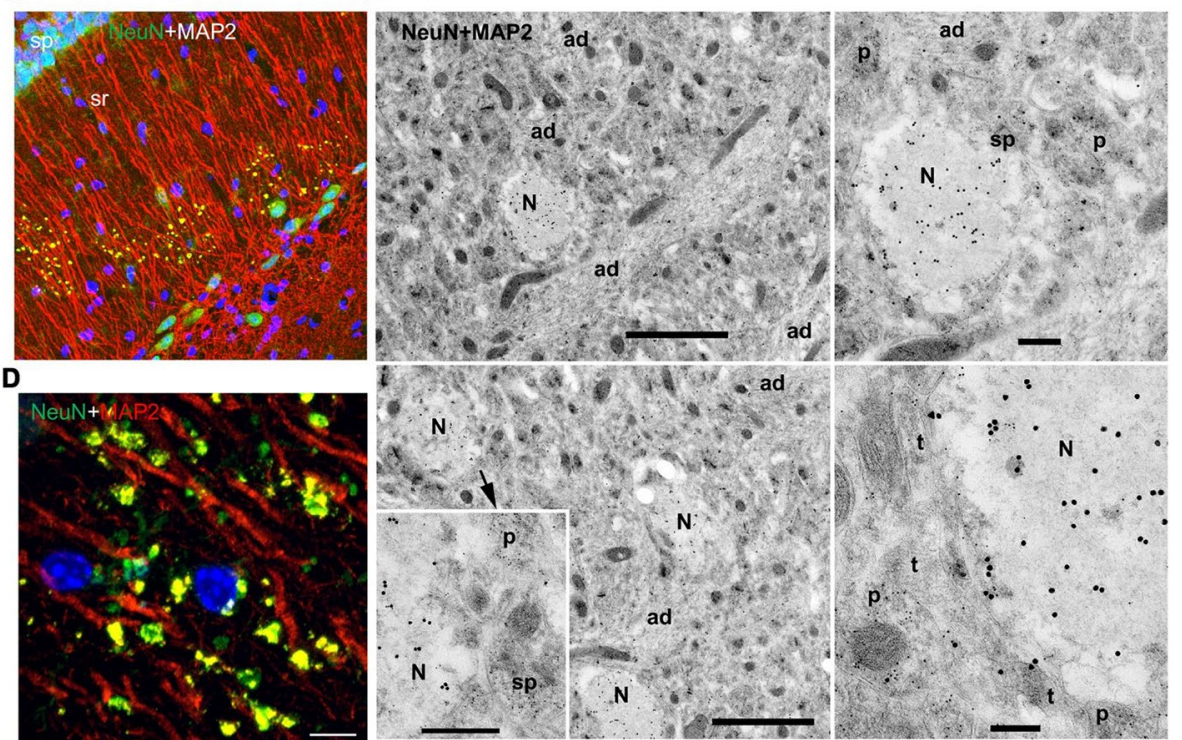

Fig. 4 The novel clusters of $\mathrm{NeuN}^{+}$puncta are formed from synaptophysin-positive presynaptic, swollen terminals and MAP2 positive postsynaptic structures. A In the CA1 region of the hippocampus of a 12-month old DPP6-KO, immunofluorescence for NeuN (green, 1:500, Millipore) and synaptophysin (red, 1:500, Sigma) show complete colocalization in clusters of the novel large puncta. On the right is a high magnification image showing the colocalized NeuN and synaptophysin in the individual, large puncta of the cluster. Scale bar $=50 \mu \mathrm{m}$. sp, stratum pyramidale; sr, stratum radiatum. B Immunogold labeling for NeuN and synaptophysin in the deep region of the CA1 (probably stratum lacunosum-moleculare) of the DPP6-KO mouse. $20 \mathrm{~nm}$ gold for NeuN is concentrated within the large swellings (arrows in low magnification image; $\mathrm{N}$ in high magnification images, $\mathbf{B i}$ and $\mathbf{B i i}$ ), where it colocalizes very well with $10 \mathrm{~nm}$ gold (arrows in high magnification images; all $10 \mathrm{~nm}$ gold particles in the image are indicated with the arrows) for synaptophysin. Both gold sizes are relatively uncommon outside of the swellings. The positions of swellings in $\mathbf{B i}$ and Bii are indicated on the low magnification, left micrograph, which has at least 10 swellings (arrows). Scale bars in Bi and Bii are $500 \mathrm{~nm}$. C, D In the CA1 of the 12-month old DPP6-KO hippocampus, immunofluorescence for NeuN (green, 1:500, Millipore) and MAP2 (red, 1:500, Millipore) are partly colocalized in the large novel puncta clusters, with MAP2 on the periphery of most NeuN ${ }^{+}$puncta and throughout some of them, as evident in the higher magnification (D); MAP2 also is evident in the apical dendrites of the CA1 pyramidal neurons that overlap with the clusters. Nuclei were counterstained with DAPI in blue. Scale bar $=5 \mu \mathrm{m}$. sp, stratum pyramidale; sr, stratum radiatum. $\mathbf{E}$ Immunogold labeling in the CA1 stratum radiatum of the 12-month DPP6-KO mouse. $20 \mathrm{~nm}$ gold for NeuN is concentrated within the large swellings ( $\mathrm{N}$ ), while $10 \mathrm{~nm}$ gold for MAP2 is mostly absent from the swellings except for a few small clusters. In contrast, the MAP2 labeling is highest in the large apical dendrites (ad) and smaller postsynaptic structures (p) including spines (sp); but presynaptic terminals (t) show little labeling. The right micrographs show higher magnifications of the swelling in the upper left micrograph. The lower left inset is magnified from the lower left micrograph. Scale bars on the left are 2 micrometers, the bar in the inset is $500 \mathrm{~nm}$, and the right scale bars are 400 and $200 \mathrm{~nm}$ for the top and bottom micrographs, respectively 
A

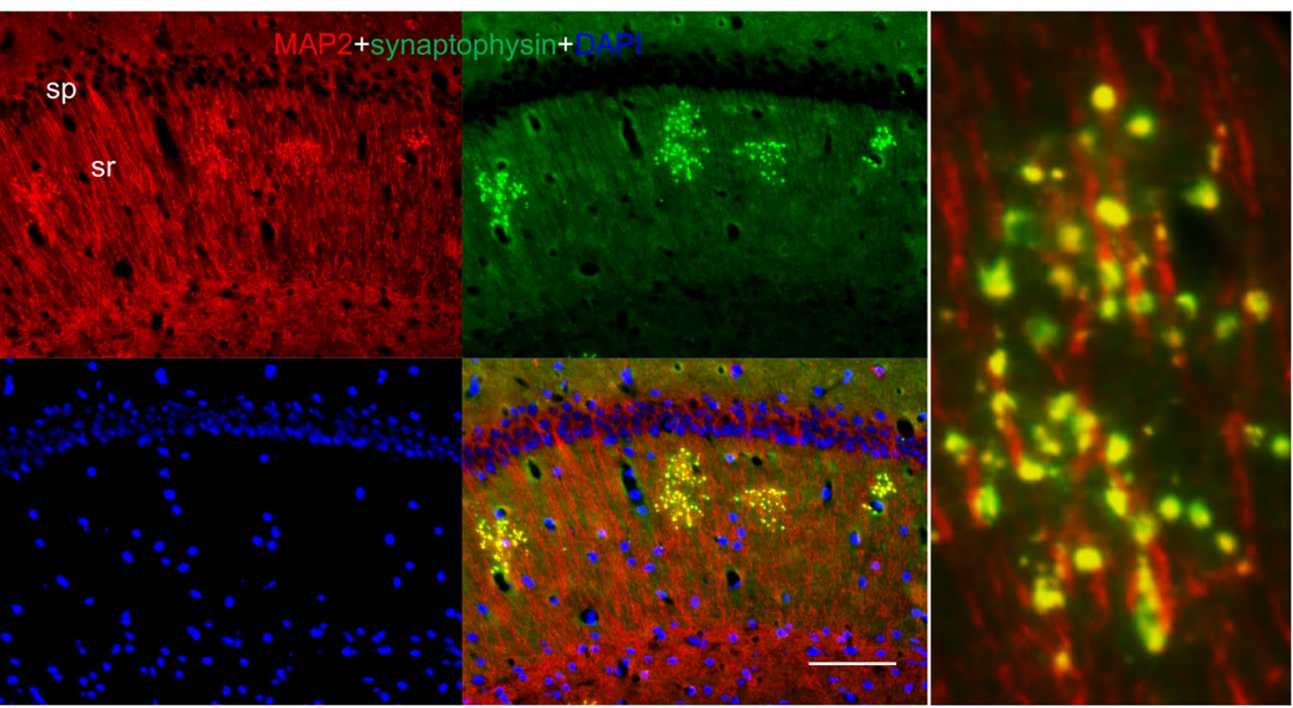

B

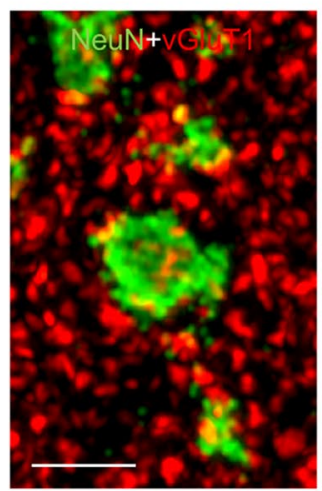

E
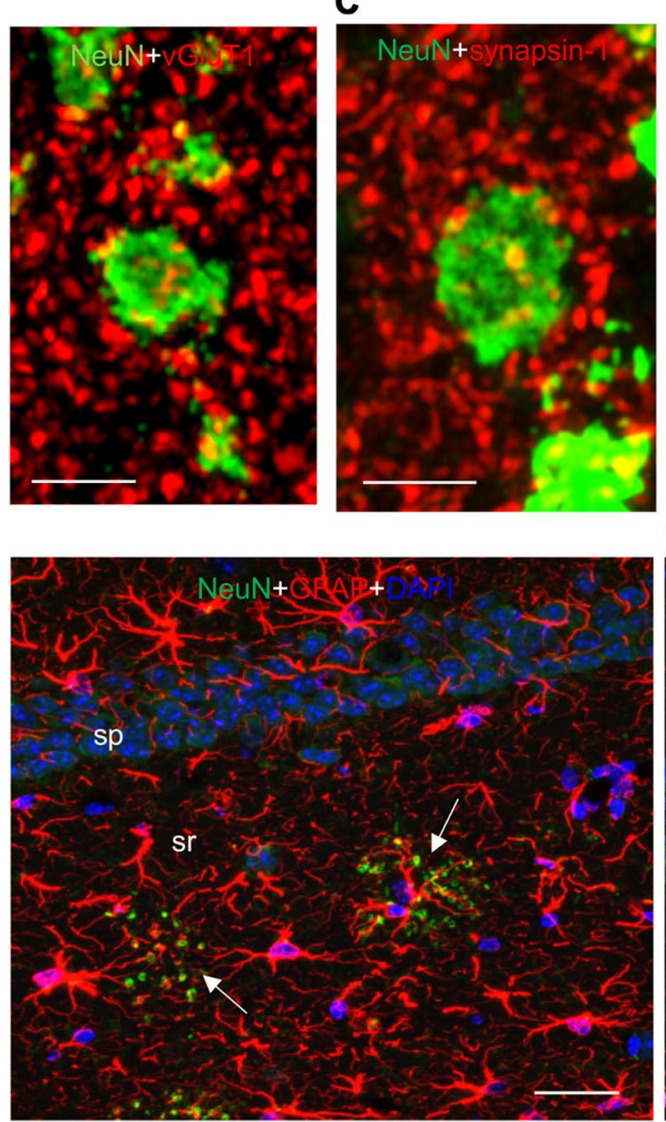

D

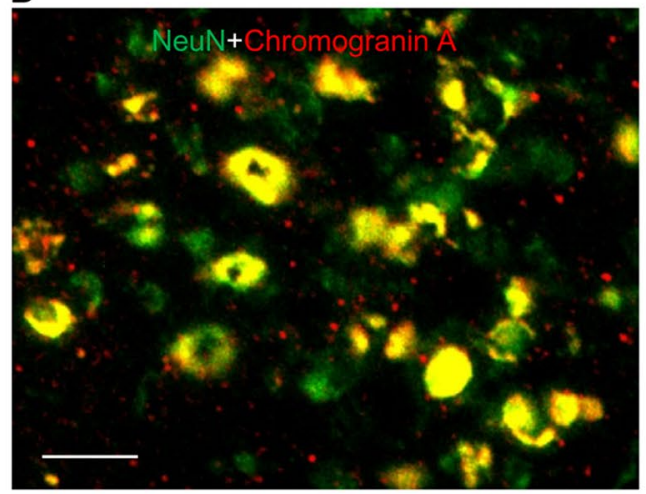

$\mathbf{F}$

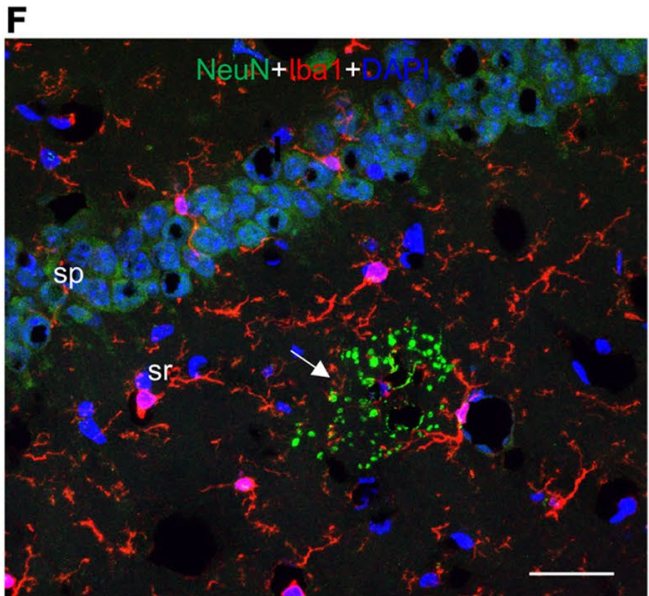

Fig. $5 \mathrm{NeuN}^{+}$clusters have partial colocalization of MAP2 and synaptophysin, strong colocalization with Chromogranin A, presynaptic markers in their periphery, and nearby glia. A In the CA1 region of the hippocampus of 12-month old DPP6-KO mice, immunofluorescence shows MAP2 (red, 1:500, Millipore) and synaptophysin (green, 1:500, Sigma) partly colocalized in clusters of puncta; on the right is the high magnification image. Scale bar $=50 \mu \mathrm{m}$. B, c Immunofluorescence staining shows the novel puncta labeled with NeuN and the presynaptic markers vGluT1 (B; red, 1:500, Millipore) and synapsin 1 (C red, 1:200, Novus), D The NeuN ${ }^{+}$novel puncta colocalize very well with Chromogranin A (red, 1:500, Novus; Scale bar $=5 \mu \mathrm{m})$. E, F The novel puncta are surrounded by astrocytes labeled with marker GFAP (E red, 1:2000, DAKO) and (F) microglia labeled with marker Iba1 (green, 1:800, Wako). Scale bar $=50 \mu \mathrm{m}$. sp, stratum pyramidale; sr, stratum radiatum. Nuclei were counterstained with DAPI in blue 


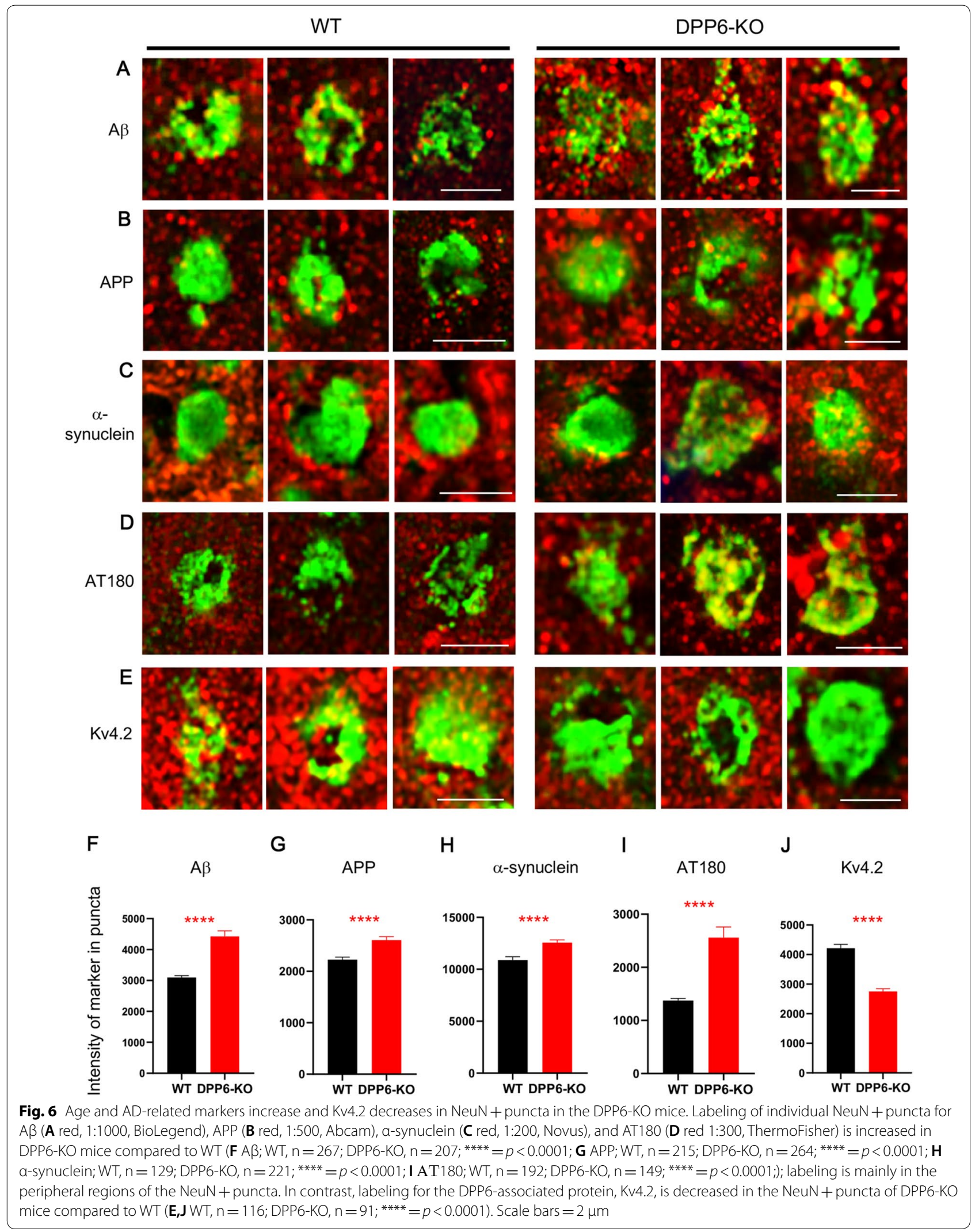




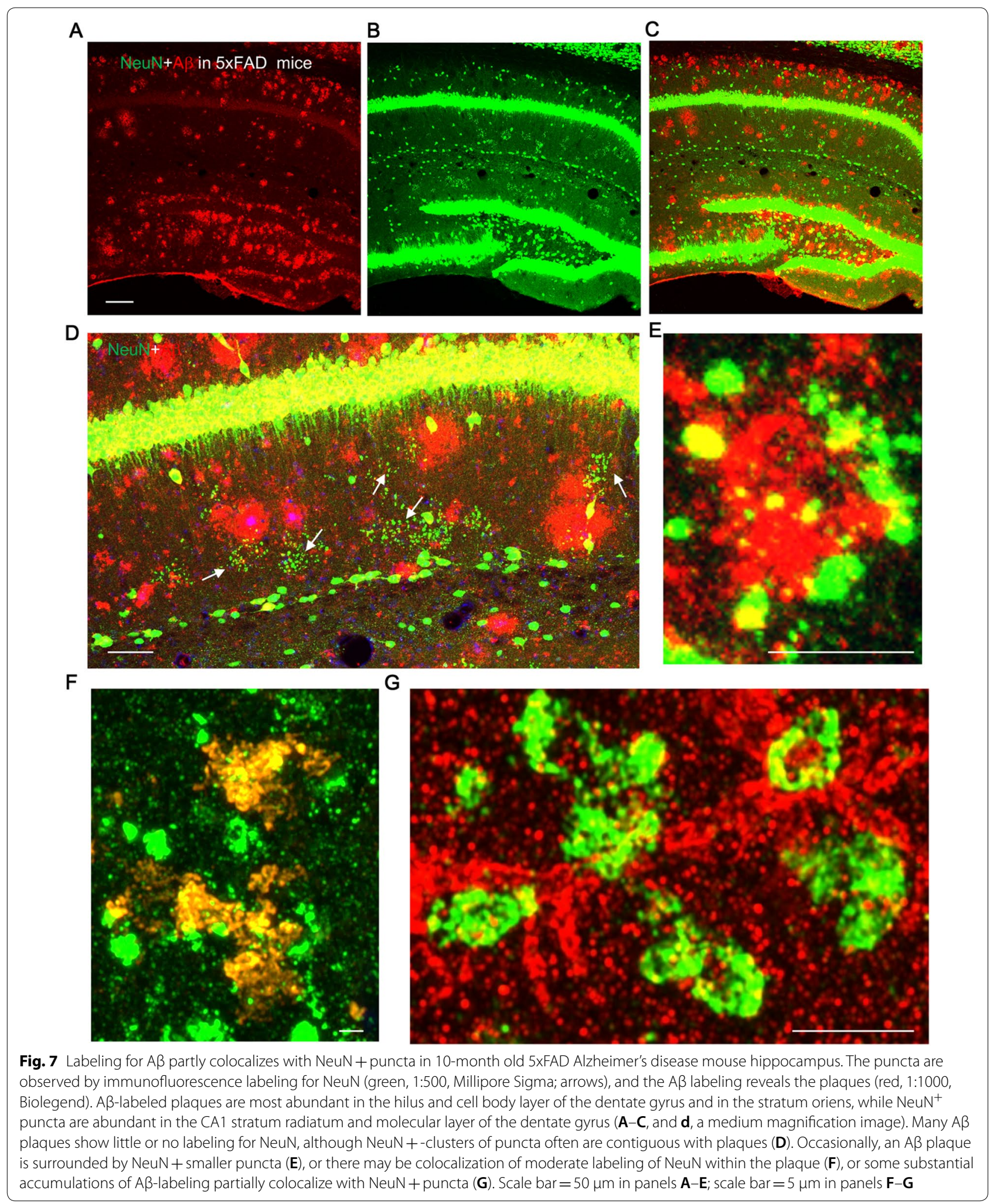


$\mathrm{NeuN}^{+}$puncta were observed in the hippocampus of an AD model mouse. We used 10-month old 5xFAD Alzheimer's disease mouse brain sections, labeling with IF for NeuN and $A \beta$ antibodies. $A \beta$-labeled plaque density was highest in the hilus and cell body layer of the dentate gyrus and in the stratum oriens (Fig. $7 \mathrm{a}-\mathrm{d}$ ). The distribution of the NeuN + puncta was actually greater in the $5 x F A D$ mice compared to either the WT or DPP6-KO mice in our study, with abundant puncta in the molecular layer of the dentate gyrus as well as in the stratum radiatum (Fig. $7 \mathrm{a}-\mathrm{d}$ ). Using low magnification confocal images, most $A \beta$ plaques showed little or no direct labeling for NeuN, although plaques and NeuN +-clusters of puncta often were contiguous (Fig. 7d). Using high resolution confocal, we found some examples of $A \beta$-labeled plaques that were surrounded by NeuN + smaller puncta (Fig. 7e), or in which there was moderate labeling of NeuN within the plaque (Fig. 7f). The latter labeling of the A $\beta$-labeled plaques for NeuN may be due to the remnants of dystrophic neurites $[7,68]$. We also found partial colocalization of labeling for $A \beta$ in or around some $\mathrm{NeuN}+$ large puncta (Fig. 7g), as described for the normal 12-month WT and DPP6-KO mice. Thus, there does appear to be some correlation of $\mathrm{NeuN}+$ puncta and plaque formation, suggesting that puncta formation may be linked somehow to the overexpression of $A \beta$ in the $5 \times$ FAD mice, especially since the NeuN + puncta are more widespread in this $\mathrm{AD}$ model compared to the DPP6-KO mice.

\section{Discussion}

\section{DPP6-KO model reveals a novel, native structure that is plaque-like and may be associated with neurodegeneration}

In this study, we have found novel clusters of large puncta in the hippocampal CA1 region in the aging brain. The presence of these clusters was increased in mice lacking the DPP6 protein. NeuN and synaptophysin are highly concentrated and completely colocalized in these structures, as seen with both IF and EM. The presence of synaptophysin in our $\mathrm{NeuN}^{+}$large puncta is consistent with our observations that these structures are modified from presynaptic terminals. This supports the ultrastructural evidence that indicates that the swellings are derived from presynaptic terminals that go through stages of change, gradually losing their evident synaptic vesicles and becoming filled with a fibrous matrix. At least in the intermediate stages of this change, active zones with synaptic vesicles continue to form on the periphery of the swelling, forming synapses with dendritic spines, presumably from the adjacent apical dendrites of the CA1 pyramidal neurons. This is shown in our ultrastructural studies and is consistent with the immunofluorescence labeling of synapsin-1 and VGluT1 found mainly on the periphery of the NeuN+synaptophysin-labeled swellings. Thus, we believe that most of the NeuN and synaptophysin, or at least those portions of these proteins with their antibody epitopes, accumulate in the growing centers of these swellings (along with chromogranin A), forming a matrix material separate from the proteins of the remaining peripheral active zones. Around the swellings, MAP2 is highest in postsynaptic structures including dendrites and their spines $[44,68]$ that closely cover the swellings, as shown in both IF and EM; both methods also indicate that MAP2 only partially colocalizes with NeuN in portions of the swellings, unlike synaptophysin. The novel puncta are characterized by the accumulation of aggregated $\mathrm{A} \beta$ peptides and chromogranin $A$, and also are colocalized with $\alpha$-synuclein, and with inflammation-associated glial cells, including both astrocytes and microglia (for reviews of gliosis in $A D$, see $[50,60])$. Like MAP2, A $\beta$-labeled structures appear to intertwine with the NeuN and synaptophysin-containing swellings. MAP2 and A $\beta$-labeling are partly colocalized, and this may be consistent with the model of Takahashi et al. $[67,68]$, who show that $A \beta$ accumulates at the distal ends of apical dendrites of the CA1 pyramidal neurons. We were not able to label the $\mathrm{A} \beta$ with our postembedding immunogold, but Takahashi et al. (2010) [67] used a pre-embedding immunogold method to show that the $A \beta$ accumulates within dendrites in the CA1 region; the associated dendritic structures shown by them would be difficult to identify without the accompanying labeling, so we were not able to identify the specific accumulations in the postsynaptic structures with our ultrastructural studies.

These novel puncta were first observed in 3-month old DPP6-KO mice with increasing accumulation during subsequent development. In contrast, they were first observed in 6-month old WT mice. The pattern of accumulation is similar to that seen for $A \beta$ plaques and tangles in $\mathrm{AD}$ in humans, where some are seen in the younger ages, accumulating with aged. The earlier and more substantial appearance of these puncta in the DPP6-KO suggest that DPP6 has a role to prevent puncta formation and deposit and prevents associated neurodegeneration. This also is supported by the presence of greater colocalization of a number of $\mathrm{AD}$ marker proteins in the puncta of DPP6-KO mice compared to WT. DPP6 could therefore play a potential role in the early clinical diagnosis and treatment of $\mathrm{AD}$ [13].

At the ultrastructural level, the $\mathrm{NeuN}^{+}$swellings resemble various structures described as Lewy bodies or Lewy pathologies in the brains of humans with 
Parkinson's disease and dementia [2, 15, 19, 46, 58, 61]; these structures are described as inclusions in neuronal somas and neurites in several brain structures including the substantia nigra, locus coeruleus, nucleus basalis of Meynert, dorsal vagus nucleus, cingulate cortical gyrus, hippocampus, etc. Similar to our described swellings, the structures in the literature often are filled with a variety of vesicular, tubulovesicular, and fibrous structures, including abnormal, deteriorating (dysmorphic) mitochondria and other organelles (described as "potentially damaged, distorted organelles" by Shahmoradian et al., 2019 [58]). Most notably, many of these published electron micrographs show a large accumulation of fibrous/ filamentous material interspersed with granular material, again very similar to what we have described here for our $\mathrm{NeuN}^{+}$swellings. Forno (1996) [19] presents an image with 2 large oval neurite swellings somewhat similar to ours, although their filamentous centers are more well-organized.

A number of immunocytochemical studies support the involvement of abnormal, enlarged presynaptic terminals in aging diseases. Lewy structures have been shown to contain $\alpha$-synuclein [2, 12, 58, 61, 72]. Similarly, we describe a strong, partial colocalization of $\alpha$-synuclein with our $\mathrm{NeuN}^{+}$large puncta with light microscopy (LM). D'Andrea et al. (2001) [12] show images of circular, "extracellular" "Lewy body-like" structures labeled with MAP2 and $\alpha$-synuclein in the substantia nigra of humans with Parkinson's disease; again, we describe a partial colocalization of these 2 proteins associated with our $\mathrm{NeuN}^{+}$large puncta. In humans with dementia with Lewy bodies, Kramer and Schulz-Schaeffer [28] found that the neurodegeneration associated with this dementia may be due mainly to $\alpha$-synuclein that forms presynaptic aggregates associated with syntaxin and synaptophysin and this phenomenon is independent of the few, large juxtanuclear, neuronal inclusions that are also $\alpha$-synuclein-positive (only the latter defined here as Lewy bodies). And in a mouse model of dementia with Lewy bodies that bears a mutation of $\alpha$-synuclein, synaptic/neuritic pathology becomes particularly prevalent in the neuropil of the hippocampus at 4 months of age and increases at 8 months of age [34]. All these studies support our finding of abnormal, enlarged synaptic terminals with associated $\alpha$-synuclein in the hippocampus in the brain of mice.

The literature also supports our finding that the $\mathrm{NeuN}^{+}$ presynaptic structures have strong labeling for synaptophysin and chromogranin A. The structures described as Lewy bodies by Nishimura et al. [46] contain both synaptophysin and chromogranin A, as we describe for our $\mathrm{NeuN}^{+}$puncta/swellings, and they note that "Synaptic vesicles are thus presumably related to the formation of
Lewy body." And Wakabayashi et al. [73] found that Lewy bodies in several regions of the brain and in sympathetic ganglia of humans with Parkinson's disease were primarily in axons, colocalizing with synaptophysin. Interestingly, labeling for synaptophysin and chromogranin A, along with A4 amyloid, also are found in the senile plaques of humans with $\mathrm{AD}$ [8]. Of course, the presence of chromogranin $\mathrm{A}$ in amyloid $\beta$ plaques is well established for human $\mathrm{AD}$ as well as for mouse models of $\mathrm{AD}$ (reviewed in Willis et al. [76]). Again, this is similar to our findings of synaptophysin, chromogranin $A$, and $A \beta$ amyloid in our NeuN ${ }^{+}$large puncta, and this is consistent with our discussion of the relationship of the $A \beta$ and the NeuN large puncta and the Takahashi papers, described above.

We also found an increase in APP in the NeuN + puncta of the DPP6-KO mice. Since APP is a component of the presynaptic membrane $[29,75]$, perhaps increased APP in DPP6-KO mice contributes to the increase in puncta size. Overexpression of APP results in increases in mammalian spine synapses [31, 74], and overexpression of an APP homolog in neuromuscular junctions in Drosophila causes a dramatic increase in the presynaptic membrane, which then expands out as buds from the main membrane [71].

Does the accumulation of a mass tangle of filaments in the $\mathrm{NeuN}^{+}$swellings include modified tau filaments? This is not clear at this point, since we have corroborated with LM and EM only the full colocalization of NeuN and synaptophysin within the central region of the swellings and their mass of filaments. Immunofluorescence shows that there is a partial overlap of pTau labeling with the $\mathrm{NeuN}^{+}$ puncta, and which extends also in areas around the $\mathrm{NeuN}^{+}$ puncta; unfortunately, we were unable to label for the pTau with EM immunogold. This partial association of the tau as well as $\mathrm{A} \beta$ amyloid with the $\mathrm{NeuN}^{+}$puncta supports the findings of Takahashi et al. [67], who found that these 2 pathologies are in the postsynaptic processes in the CA1 area. The structure of tau filaments has been described $[18,39,70]$, and ultrastructural studies reveal that these filaments are distributed mainly in neuron somas and dendrites $[1,27,38,70]$, while their presence in the presynaptic compartments is less clear $[1,38,78]$. In studies of mutant mice expressing human tau, several studies $[38,54,62$, 70] found swollen myelinated axon portions called "spheroids" filled with a mixture of neurofilaments, and having labeling for tau. While these latter studies did not find tau accumulations in axon terminals, in general, dystrophic, swollen axonal terminals may be associated with various neuronal pathologies, and perhaps are due to disorders in axonal transport. For dementia, the axonopathy may be due to the effects of abnormal tau protein accumulation, as discussed by Lin et al. (2003) [38] and Terwel et al. 

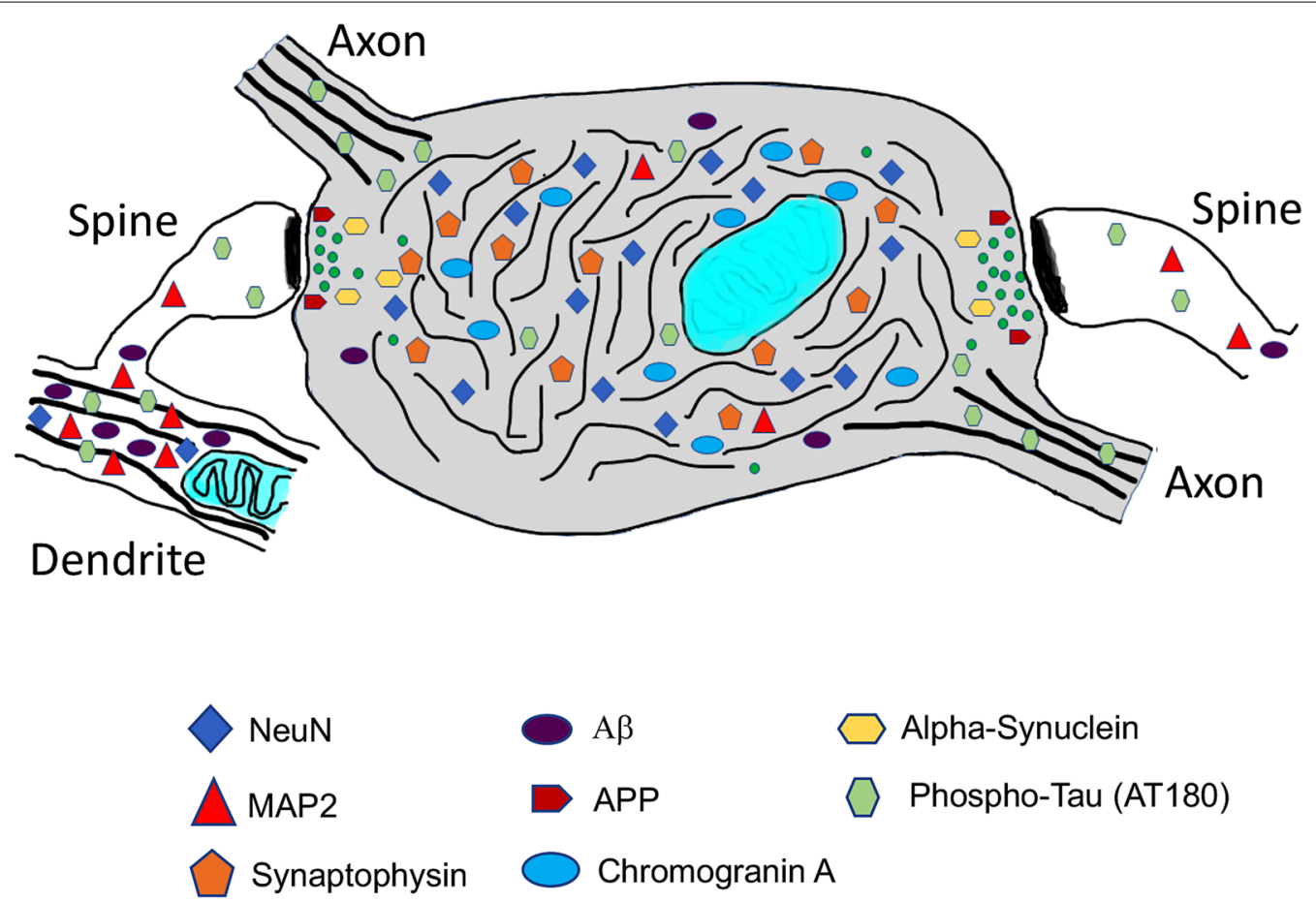

\section{Synaptic vesicle (vGluT1+Synapsin-1)}

Fig. 8 A summary drawing of a NeuN + punctum showing how the various synapse-related and AD-related proteins appear to be arranged. It is based on both the data presented and the published literature. It is portrayed as a presynaptic terminal swelling that forms synapses with two postsynaptic spines (black band represents the postsynaptic density); the left spine is shown extending from its parent dendrite. Microtubules in the axon and dendrite are illustrated with thick black lines and neurofilaments in the swelling are illustrated with thin black lines. The dendrite has a normal mitochondrion (teal color) with distinct cristae (curved lines) while the mitochondrion in the swelling is shown as a dysmorphic (deteriorating) one with indistinct cristae. The main portion of the abnormal terminal swelling is filled with NeuN, synaptophysin, and chromogranin A, while other proteins are concentrated more on the periphery, either in the dwindling presynaptic terminal active zones or the associated postsynaptic structures

[70]. Thus, ultrastructural studies of the brain of patients with Alzheimer's presenile dementia found dendritic and axonal processes that were swollen with neurofilaments [69]. Swollen, unmyelinated "spheroids" filled with neurofilaments and tubulin have been found in the dentate gyrus of the hippocampus of patients with frontotemporal dementia; these contained only a few tau filaments [78]. Light microscope localization of synaptophysin indicated that they might be presynaptic structures; however, EM studies showed that these structures lacked synaptic vesicles and synapses. Perhaps these are equivalent to the later stage swellings in our study in which synaptic vesicles are no longer present. Based on these previous studies combined with our findings, it is likely that the swellings in the CA1 in our study are filled with neurofilaments, perhaps containing tau filaments as well.

The distribution of NeuN-swellings does not seem to correlate with a specific pattern of innervation. The clusters of large $\mathrm{NeuN}^{+}$puncta are found in the CA1 stratum radiatum, oriens and lacunosum-moleculare, and each large punctum is centered around a swollen presynaptic terminal that is probably excitatory, glutamatergic since there is substantial labeling for VGluT1 on the periphery of the $\mathrm{NeuN}^{+}$punctum, and ultrastructural analysis indicates that the swellings have peripheral, asymmetric synapses on postsynaptic spines. Interestingly, we also have found similar clusters of large, NeuN and synaptophysin-positive puncta in the outer layer of parts of the olfactory cortex, including the piriform cortex and adjacent piriform-amygdala area ventral to this (Additional file 2: 2C,D). Both the hippocampus CA1 and this part of the cortex have a roughly similar basic structural organization, especially centered on the apical dendrites of pyramidal neurons [51, 59]; and adjacent, associated areas of the cortex (entorhinal, perirhinal) along with CA1 are the earliest targets of neurofibrillary tangles associated with $\mathrm{AD}$ [42]. The $\mathrm{NeuN}^{+}$clusters in the olfactory cortical areas could originate from axonal input from local pyramidal neurons, e.g., the extensive axon collaterals from pyramidal neurons of the piriform 
cortex [24], or perhaps from the olfactory bulb afferents, which specifically innervate the outer layer. However, there doesn't seem to be any one particular, major excitatory innervation of the CA1 that ends in all of its layers. An alternative source of the large $\mathrm{NeuN}^{+}$puncta, other than a glutamatergic input, could be dopaminergic, since the CA1 region has the highest dopaminergic innervation of the hippocampus [16]; but labeling with antibodies to tyrosine hydroxylase and vMAT2 did not show any notable colocalization with the $\mathrm{NeuN}^{+}$puncta (data not shown). Nor was there any particular association of the $\mathrm{NeuN}^{+}$puncta with GAD67; so, a particular inhibitory neuron source is not likely. Perhaps the arrangement of $\mathrm{NeuN}^{+}$clusters is not tied to a particular innervation pattern but reflects more a local pattern of cells in CA1.

A summary diagram of a NeuN+ punctum (Fig. 8) shows how the various synapse-related and AD-related proteins appear to be arranged, based on both the data presented here and the published literature discussed above. It shows how the main portion of the abnormal terminal swelling is filled with NeuN, synaptophysin, and chromogranin A, while other proteins are concentrated more on the periphery, either in the dwindling presynaptic terminal active zones or the associated postsynaptic structures.

\section{DPP6 may play an important neuroprotective role in the prevention of neurodegeneration}

Aging is the most important risk factor for the development of neurodegenerative disease and most neurodegenerative disorders manifest in the elderly [26]. A key region of the aging brain associated with neurodegeneration is the hippocampus. In fact, Maruszak and Thuret (2014) [42] note that hippocampal "...dysfunction is believed to underlie the core feature of the disease-memory impairment..." in AD. Our description here of a novel structure in the hippocampus that is observed natively in the aging mouse brain, but which develops sooner and at higher frequency in DPP6-KO mice suggests that DPP6 may normally play an important role in synapse maintenance. Abnormal, enlarged presynaptic terminals in aging diseases are likely associated with neurodegeneration.

\section{Supplementary information}

Supplementary information accompanies this paper at https://doi. org/10.1186/s40478-020-01065-7.

Additional file 1: Fig. S1 Immunogold labeling of swellings (N) with NeuN $(20 \mathrm{~nm})$ in the deep region of the CA1 (deep stratum radiatum and adjacent lacunosum-moleculare) of the hippocampus of a DPP6-KO 12-month old mouse. In $\mathbf{a}$ and $\mathbf{b}$, note the presynaptic active zones ( $p$ ) that are in the periphery of the swelling and form synapses with postsynaptic spines (sp). Ad, apical dendrites of CA1 pyramidal neurons; $m$, dysmorphic (deteriorating) mitochondria in the center of the swelling in C. Scale bar is $500 \mathrm{~nm}$
Additional file 2: Fig. S2 A, B: In the CA1 region of the hippocampus of 12-month old DPP6-KO mice, the immunofluorescence (IF) shows that NeuN (green, 1:500, Millipore Sigma) labeling in the puncta is not colocalized with either GAD67 (A. red, 1:2000, Abcam) or ubiquitin (B, red, 1:1000, Abcam). Scale bar $=50 \mu \mathrm{m}$. C: NeuN + puncta found in the piriform cortex. In 12-month old DPP6 mice, IF shows NeuN + puncta located in the piriform cortex. Scale bar $=1 \mathrm{~mm}$; the pirform cortex is magnified in the image on the right. Nuclei were counterstained with DAPI in blue

\section{Acknowledgements}

This work was supported by the Intramural Research Program of the Eunice Kennedy Shriver National Institute of Child Health and Human Development. RSP and Y-XW were supported by the Intramural Research Program of $\mathrm{NIH} /$ National Institute on Deafness and Other Communication Disorders (NIDCD) (Advanced Imaging Core-ZIC DC000081). We thank Dr. Hoffman's lab members, Yujun Hou (NCl) and Rose Marie Karlsson (NIMH) for helpful suggestions. We also thank the NIH NICHD Microscopy and Imaging core, including Lynne Holtzclaw, Vincent Schram, and also Connie Mackenzie-Gray Scott and Daniel Abebe from NICHD for technical assistance.

\section{Author contributions}

$\mathrm{LL}, \mathrm{RSP}$ and DAH designed the experiments and wrote the manuscript; LL, RSP performed experiments; $L L$ analyzed the data. RL and Y-XW helped perform experiments.

\section{Competing interests}

The authors declare that they have no competing interests.

\section{Author details}

${ }^{1}$ Molecular Neurophysiology and Biophysics Section, Program in Developmental Neuroscience, Eunice Kennedy Shriver National Institute of Child Health and Human Development, 35 Lincoln Drive, MSC 3715, Building 35, Room 3C-905, Bethesda, MD 20892-3715, USA. ${ }^{2}$ Advanced Imaging Core, National Institute on Deafness and Other Communication Disorders, Bethesda, MD 20892-3715, USA. ${ }^{3}$ Laboratory of Genitourinary Cancer Pathogenesis, National Cancer Institute, National Institutes of Health, Bethesda, MD 20892, USA.

Received: 13 October 2020 Accepted: 17 October 2020

Published online: 23 November 2020

References

1. Arima K (2006) Ultrastructural characteristics of tau filaments in tauopathies: immuno-electron microscopic demonstration of tau filaments in tauopathies. Neuropathology 26:475-483. https://doi.org/10.111 1/j.1440-1789.2006.00669.x

2. Arima K, Ueda K, Sunohara N, Hirai S, Izumiyama Y, Tonozuka-Uehara H, Kawai M (1998) Immunoelectron-microscopic demonstration of NACP/ alpha-synuclein-epitopes on the filamentous component of Lewy bodies in Parkinson's disease and in dementia with Lewy bodies. Brain Res 808:93-100

3. Ballatore C, Lee VM, Trojanowski JQ (2007) Tau-mediated neurodegeneration in Alzheimer's disease and related disorders. Nat Rev Neurosci 8:663-672. https://doi.org/10.1038/nrn2194

4. Biernat J, Mandelkow EM (1999) The development of cell processes induced by tau protein requires phosphorylation of serine 262 and 356 in the repeat domain and is inhibited by phosphorylation in the proline-rich domains. Mol Biol Cell 10:727-740. https://doi.org/10.1091/ mbc. 10.3.727

5. Biernat J, Wu YZ, Timm T, Zheng-Fischhöfer Q, Mandelkow E, Meijer L, Mandelkow EM (2002) Protein kinase MARK/PAR-1 is required for neurite outgrowth and establishment of neuronal polarity. Mol Biol Cell 13:4013-4028. https://doi.org/10.1091/mbc.02-03-0046

6. Bock I, Nemeth K, Pentelenyi K, Balicza P, Balazs A, Molnar MJ, Roman V, Nagy J, Levay G, Kobolak J, Dinnyes A (2016) Targeted next generation sequencing of a panel of autism-related genes identifies an EHMT1 
mutation in a Kleefstra syndrome patient with autism and normal intellectual performance. Gene 595:131-141

7. Boon BDC, Bulk M, Jonker AJ, Morrema THJ, van den Berg E, Popovic M, Walter J, Kumar S, van der Lee SJ, Holstege H, Zhu X, Van Nostrand WE, Natté $R$, van der Weerd $L$, Bouwman FH, van de Berg WDJ, Rozemuller AJM, Hoozemans JJM (2020) The coarse-grained plaque: a divergent A $\beta$ plaque-type in early-onset Alzheimer's disease. Acta Neuropathol. https ://doi.org/10.1007/s00401-020-02198-8

8. Brion JP, Couck AM, Bruce M, Anderton B, Flament-Durand J (1991) Synaptophysin and chromogranin A immunoreactivities in senile plaques of Alzheimer's disease. Brain Res 539:143-150

9. Cacace R, Heeman B, Van Mossevelde S, De Roeck A, Hoogmartens J, De Rijk P, Gossye H, De Vos K, De Coster W, Strazisar M, De Baets G, Schymkowitz J, Rousseau F, Geerts N, De Pooter T, Peeters K, Sieben A, Martin JJ, Engelborghs S, Salmon E, Santens P, Vandenberghe R, Cras P et al (2019) Loss of DPP6 in neurodegenerative dementia: a genetic player in the dysfunction of neuronal excitability. Acta Neuropathol 137:901-918. https:// doi.org/10.1007/s00401-019-01976-3

10. Caselli RJ, Beach TG, Knopman DS, Graff-Radford NR (2017) Alzheimer disease: scientific breakthroughs and translational challenges. Mayo Clin Proc 92:978-994. https://doi.org/10.1016/j.mayocp.2017.02.011

11. Cho JH, Johnson GV (2004) Primed phosphorylation of tau at Thr231 by glycogen synthase kinase 3beta (GSK3beta) plays a critical role in regulating tau's ability to bind and stabilize microtubules. J Neurochem 88:349-358. https://doi.org/10.1111/j.1471-4159.2004.02155.x

12. D'Andrea MR, llyin S, Plata-Salaman CR (2001) Abnormal patterns of microtubule-associated protein-2 (MAP-2) immunolabeling in neuronal nuclei and Lewy bodies in Parkinson's disease substantia nigra brain tissues. Neurosci Lett 306:137-140

13. DeTure MA, Dickson DW (2019) The neuropathological diagnosis of Alzheimer's disease. Mol Neurodegener 14:32. https://doi.org/10.1186/s1302 4-019-0333-5

14. Duan W, Zhang YP, Hou Z, Huang C, Zhu H, Zhang CQ, Yin Q (2016) Novel insights into NeuN: from neuronal marker to splicing regulator. Mol Neurobiol 53:1637-1647. https://doi.org/10.1007/s12035-015-9122-5

15. Duffy P, Tennyson V (1965) Phase and electron microscopic observations of Lewy bodies and melanin granules in the substantia nigra and locus caeruleus in Parkinson's Disease. J Neuropathol Experiment Neurol 24:1

16. Edelmann E, Lessmann V (2018) Dopaminergic innervation and modulation of hippocampal networks. Cell Tissue Res 373:711-727. https://doi. org/10.1007/s00441-018-2800-7

17. Egger G, Roetzer KM, Noor A, Lionel AC, Mahmood H, Schwarzbraun $T$, Boright O, Mikhailov A, Marshall CR, Windpassinger C, Petek E, Scherer SW, Kaschnitz W, Vincent JB (2014) Identification of risk genes for autism spectrum disorder through copy number variation analysis in Austrian families. Neurogenetics 15:117-127

18. Fitzpatrick AWP, Falcon B, He S, Murzin AG, Murshudov G, Garringer HJ, Crowther RA, Ghetti B, Goedert M, Scheres SHW (2017) Cryo-EM structures of tau filaments from Alzheimer's disease. Nature 547:185-190. https://doi.org/10.1038/nature23002

19. Forno L (1996) Neuropathology of Parkinson's disease. J Neuropathol Exp Neurol 55:259

20. Gouras GK, Tsai J, Naslund J, Vincent B, Edgar M, Checler F, Greenfield JP, Haroutunian V, Buxbaum JD, Xu H, Greengard P, Relkin NR (2000) Intraneuronal Abeta42 accumulation in human brain. Am J Pathol 156:15-20. https://doi.org/10.1016/s0002-9440(10)64700-1

21. Gyure KA, Durham R, Stewart WF, Smialek JE, Troncoso JC (2001) Intraneuronal abeta-amyloid precedes development of amyloid plaques in Down syndrome. Arch Pathol Lab Med 125:489-492. https://doi. org/10.1043/0003-9985(2001)125\%3c0489:iaapdo\%3e2.0.co;2

22. Han W, Li J, Pelkey KA, Pandey S, Chen X, Wang YX, Wu K, Ge L, LiT, Castellano D, Liu C, Wu LG, Petralia RS, Lynch JW, McBain CJ, Lu W (2019) Shisa7 is a GABA(A) receptor auxiliary subunit controlling benzodiazepine actions. Science 366:246-250. https://doi.org/10.1126/science.aax5719

23. Hoffman DA, Magee JC, Colbert CM, Johnston D (1997) K+ channel regulation of signal propagation in dendrites of hippocampal pyramidal neurons. Nature 387:869-875. https://doi.org/10.1038/43119

24. Johnson DM, Illig KR, Behan M, Haberly LB (2000) New features of connectivity in piriform cortex visualized by intracellular injection of pyramidal cells suggest that "primary" olfactory cortex functions like "association" cortex in other sensory systems. J Neurosci 20:6974-6982. https://doi. org/10.1523/jneurosci.20-18-06974.2000

25. Johnson GV, Stoothoff WH (2004) Tau phosphorylation in neuronal cell function and dysfunction. J Cell Sci 117:5721-5729. https://doi. org/10.1242/jcs.01558

26. Johnson IP (2015) Age-related neurodegenerative disease research needs aging models. Front Aging Neurosci 7:168. https://doi.org/10.3389/fnagi .2015 .00168

27. Kidd M (1964) Alzheimer's disease —an electron microscopical study. Brain: J Neurol 87:307-320. https://doi.org/10.1093/brain/87.2.307

28. Kramer ML, Schulz-Schaeffer WJ (2007) Presynaptic alpha-synuclein aggregates, not Lewy bodies, cause neurodegeneration in dementia with Lewy bodies. J Neurosci 27:1405-1410. https://doi.org/10.1523/jneur osci.4564-06.2007

29. Laßek M, Weingarten J, Einsfelder U, Brendel P, Müller U, Volknandt W (2013) Amyloid precursor proteins are constituents of the presynaptic active zone. J Neurochem 127:48-56. https://doi.org/10.1111/jnc.12358

30. Lechner T, Adlassnig C, Humpel C, Kaufmann WA, Maier H, ReinstadlerKramer K, Hinterhölzl J, Mahata SK, Jellinger KA, Marksteiner J (2004) Chromogranin peptides in Alzheimer's disease. Exp Gerontol 39:101-113. https://doi.org/10.1016/j.exger.2003.09.018

31. Lee KJ, Moussa CE, Lee Y, Sung Y, Howell BW, Turner RS, Pak DT, Hoe HS (2010) Beta amyloid-independent role of amyloid precursor protein in generation and maintenance of dendritic spines. Neuroscience 169:344-356. https://doi.org/10.1016/j.neuroscience.2010.04.078

32. Li J, Han W, Pelkey KA, Duan J, Mao X, Wang YX, Craig MT, Dong L, Petralia RS, McBain CJ, Lu W (2017) Molecular dissection of neuroligin 2 and Slitrk3 reveals an essential framework for GABAergic synapse development. Neuron 96(808-826):e808. https://doi.org/10.1016/j.neuron.2017.10.003

33. Liao C, Fu F, Li R, Yang WQ, Liao HY, Yan JR, Li J, Li SY, Yang X, Li DZ (2013) Loss-of-function variation in the DPP6 gene is associated with autosomal dominant microcephaly and mental retardation. Eur J Med Genet 56:484-489

34. Lim Y, Kehm VM, Lee EB, Soper JH, Li C, Trojanowski JQ, Lee VM (2011) alpha-Syn suppression reverses synaptic and memory defects in a mouse model of dementia with Lewy bodies. J Neurosci 31:10076-10087. https ://doi.org/10.1523/jneurosci.0618-11.2011

35. Lin L, Long LK, Hatch MM, Hoffman DA (2014) DPP6 domains responsible for its localization and function. J Biol Chem 289:32153-32165

36. Lin L, Murphy JG, Karlsson RM, Petralia RS, Gutzmann JJ, Abebe D, Wang YX, Cameron HA, Hoffman DA (2018) DPP6 loss impacts hippocampal synaptic development and induces behavioral impairments in recognition, learning and memory. Front Cell Neurosci 12:84

37. Lin L, Sun W, Throesch B, Kung F, Decoster JT, Berner CJ, Cheney RE, Rudy B, Hoffman DA (2013) DPP6 regulation of dendritic morphogenesis impacts hippocampal synaptic development. Nat Commun 4:2270

38. Lin WL, Lewis J, Yen SH, Hutton M, Dickson DW (2003) Ultrastructural neuronal pathology in transgenic mice expressing mutant (P301L) human tau. J Neurocytol 32:1091-1105

39. Lippens G, Gigant B (2019) Elucidating Tau function and dysfunction in the era of cryo-EM. J Biol Chem 294:9316-9325. https://doi.org/10.1074/ jbc.rev119.008031

40. Lucas CH, Calvez M, Babu R, Brown A (2014) Altered subcellular localization of the NeuN/Rbfox3 RNA splicing factor in HIV-associated neurocognitive disorders (HAND). Neurosci Lett 558:97-102. https://doi. org/10.1016/j.neulet.2013.10.037

41. Marshall CR, Noor A, Vincent JB, Lionel AC, Feuk L, Skaug J, Shago M, Moessner R, Pinto D, Ren Y, Thiruvahindrapduram B, Fiebig A, Schreiber S, Friedman J, Ketelaars CE, Vos YJ, Ficicioglu C, Kirkpatrick S, Nicolson R, Sloman L, Summers A, Gibbons CA, Teebi A, Chitayat D, Weksberg R, Thompson A, Vardy C, Crosbie V, Luscombe S, Baatjes R, Zwaigenbaum L, Roberts W, Fernandez B, Szatmari P, Scherer SW (2008) Structural variation of chromosomes in autism spectrum disorder. Am J Hum Genet 82:477-488

42. Maruszak A, Thuret S (2014) Why looking at the whole hippocampus is not enough-a critical role for anteroposterior axis, subfield and activation analyses to enhance predictive value of hippocampal changes for Alzheimer's disease diagnosis. Front Cell Neurosci 8:95. https://doi.org/10.3389/ fncel.2014.00095

43. Maussion G, Cruceanu C, Rosenfeld JA, Bell SC, Jollant F, Szatkiewicz J, Collins RL, Hanscom C, Kolobova I, de Champfleur NM, Blumenthal I, 
Chiang C, Ota V, Hultman C, O'Dushlaine C, McCarroll S, Alda M, Jacquemont S, Ordulu Z, Marshall CR, Carter MT, Shaffer LG, Sklar P, Girirajan S, Morton CC, Gusella JF, Turecki G, Stavropoulos DJ, Sullivan PF, Scherer SW, Talkowski ME, Ernst C (2017) Implication of LRRC4C and DPP6 in neurodevelopmental disorders. Am J Med Genet A 173:395-406

44. Morales MaF, E (1989) Distribution of MAP 2 in dendritic spines and its colocalization with actin

45. Nadal MS, Ozaita A, Amarillo Y, Vega-Saenz de Miera E, Ma Y, Mo W, Goldberg EM, Misumi Y, Ikehara Y, Neubert TA, Rudy B (2003) The CD26-related dipeptidyl aminopeptidase-like protein DPPX is a critical component of neuronal A-type K+ channels. Neuron 37:449-461

46. Nishimura M, Tomimoto, H, Suenaga, T, Nakamura, S, Namba, Y, Ikeda, K, Akiguchi, I, Kimura, J (1994) Synaptophysin and chromogranin A immunoreactivities of Lewy bodies in Parkinson's disease brains

47. Noor A, Whibley A, Marshall CR, Gianakopoulos PJ, Piton A, Carson AR, Orlic-Milacic M, Lionel AC, Sato D, Pinto D, Drmic I, Noakes C, Senman L, Zhang X, Mo R, Gauthier J, Crosbie J, Pagnamenta AT, Munson J, Estes AM, Fiebig A, Franke A, Schreiber S, Stewart AF, Roberts R, McPherson R, Guter SJ, Cook EH, Jr., Dawson G, Schellenberg GD, Battaglia A, Maestrini E, Jeng L, Hutchison T, Rajcan-Separovic E, Chudley AE, Lewis SM, Liu X, Holden JJ, Fernandez B, Zwaigenbaum L, Bryson SE, Roberts W, Szatmari P, Gallagher L, Stratton MR, Gecz J, Brady AF, Schwartz CE, Schachar RJ, Monaco AP, Rouleau GA, Hui CC, Lucy Raymond F, Scherer SW, Vincent JB (2010) Disruption at the PTCHD1 Locus on Xp22.11 in Autism spectrum disorder and intellectual disability. Sci Transl Med 2:49ra68

48. Oddo S, Billings L, Kesslak JP, Cribbs DH, LaFerla FM (2004) Abeta immunotherapy leads to clearance of early, but not late, hyperphosphorylated tau aggregates via the proteasome. Neuron 43:321-332. https://doi. org/10.1016/j.neuron.2004.07.003

49. Oddo S, Caccamo A, Shepherd JD, Murphy MP, Golde TE, Kayed R, Metherate R, Mattson MP, Akbari Y, LaFerla FM (2003) Triple-transgenic model of Alzheimer's disease with plaques and tangles: intracellular Abeta and synaptic dysfunction. Neuron 39:409-421. https://doi.org/10.1016/s0896 $-6273(03) 00434-3$

50. Osborn LM, Kamphuis W, Wadman WJ, Hol EM (2016) Astrogliosis: an integral player in the pathogenesis of Alzheimer's disease. Prog Neurobiol 144:121-141. https://doi.org/10.1016/j.pneurobio.2016.01.001

51. Paxinos $G$ (2004) The rat nervous system, 3rd edn. Academic Press, New York

52. Petralia RS, Wang YX, Hua F, Yi Z, Zhou A, Ge L, Stephenson FA, Wenthold RJ (2010) Organization of NMDA receptors at extrasynaptic locations. Neuroscience 167:68-87. https://doi.org/10.1016/j.neuroscien ce.2010.01.022

53. Pottier C, Ren Y, Perkerson RB 3rd, Baker M, Jenkins GD, van Blitterswijk M, DeJesus-Hernandez M, van Rooij JGJ, Murray ME, Christopher E, MCDonnell SK, Fogarty Z, Batzler A, Tian S, Vicente CT, Matchett B, Karydas AM, Hsiung GR, Seelaar H, Mol MO, Finger EC, Graff C, Oijerstedt L, Neumann M, Heutink P, Synofzik M, Wilke C, Prudlo J, Rizzu P, Simon-Sanchez J, Edbauer D, Roeber S, Diehl-Schmid J, Evers BM, King A, Mesulam MM, Weintraub S, Geula C, Bieniek KF, Petrucelli L, Ahern GL, Reiman EM, Woodruff BK, Caselli RJ, Huey ED, Farlow MR, Grafman J, Mead S, Grinberg LT, Spina S, Grossman M, Irwin DJ, Lee EB, Suh E, Snowden J, Mann D, Ertekin-Taner N, Uitti RJ, Wszolek ZK, Josephs KA, Parisi JE, Knopman DS, Petersen RC, Hodges JR, Piguet O, Geier EG, Yokoyama JS, Rissman RA, Rogaeva E, Keith J, Zinman L, Tartaglia MC, Cairns NJ, Cruchaga C, Ghetti B, Kofler J, Lopez OL, Beach TG, Arzberger T, Herms J, Honig LS, Vonsattel JP, Halliday GM, Kwok JB, White CL 3rd, Gearing M, Glass J, Rollinson S, Pickering-Brown S, Rohrer JD, Trojanowski JQ, Van Deerlin V, Bigio EH, Troakes C, Al-Sarraj S, Asmann Y, Miller BL, Graff-Radford NR, Boeve BF, Seeley WW, Mackenzie IRA, van Swieten JC, Dickson DW, Biernacka JM, Rademakers R (2019) Genome-wide analyses as part of the international FTLD-TDP whole-genome sequencing consortium reveals novel disease risk factors and increases support for immune dysfunction in FTLD. Acta Neuropathol 137:879-899. https://doi.org/10.1007/s00401-019-01962-9

54. Probst A, Gotz J, Wiederhold KH, Tolnay M, Mistl C, Jaton AL, Hong M, Ishihara T, Lee VM, Trojanowski JQ, Jakes R, Crowther RA, Spillantini MG, Burki K, Goedert M (2000) Axonopathy and amyotrophy in mice transgenic for human four-repeat tau protein. Acta Neuropathol 99:469-481

55. Prontera P, Napolioni V, Ottaviani V, Rogaia D, Fusco C, Augello B, Serino D, Parisi V, Bernardini L, Merla G, Cavanna AE, Donti E (2014) DPP6 gene disruption in a family with Gilles de la Tourette syndrome. Neurogenetics $15: 237-242$

56. Rahman MM, Uddin KF, Al Jezawi NK, Karuvantevida N, Akter H, Dity NJ, Rahaman MA, Begum M, Rahaman MA, Baqui MA, Salwa Z, Islam S, Woodbury-Smith M, Basiruzzaman M, Uddin M (2019) Gonadal mosaicism of large terminal de novo duplication and deletion in siblings with variable intellectual disability phenotypes. Mol Genet Genomic Med 7:e00954

57. Schultz C, Del Tredici K (2004) In Alzheimer's disease current clinical neurology. Humana Press, Neuropathology of Alzheimer's Disease

58. Shahmoradian SH, Lewis AJ, Genoud C, Hench J, Moors TE, Navarro PP, Castano-Diez D, Schweighauser G, Graff-Meyer A, Goldie KN, Sutterlin R, Huisman E, Ingrassia A, Gier Y, Rozemuller AJM, Wang J, Paepe A, Erny J, Staempfli A, Hoernschemeyer J, Grosseruschkamp F, Niedieker D, El-Mashtoly SF, Quadri M, Van IWFJ, Bonifati V, Gerwert K, Bohrmann B, Frank S, Britschgi M, Stahlberg H, Van de Berg WDJ, Lauer ME (2019) Lewy pathology in Parkinson's disease consists of crowded organelles and lipid membranes. Nat Neurosci 22:1099-1109. https://doi.org/10.1038/s4159 3-019-0423-2

59. Shepherd GM (2004) The synaptic organization of the brain. Oxford University Press, New York

60. Spanic E, Langer Horvat L, Hof PR, Simic G (2019) Role of microglial cells in Alzheimer's disease tau propagation. Front Aging Neurosci 11:271. https://doi.org/10.3389/fnagi.2019.00271

61. Spillantini MG, Crowther RA, Jakes R, Hasegawa M, Goedert M (1998) alpha-Synuclein in filamentous inclusions of Lewy bodies from Parkinson's disease and dementia with lewy bodies. Proc Natl Acad Sci USA 95:6469-6473

62. Spittaels K, Van den Haute C, Van Dorpe J, Bruynseels K, Vandezande K, Laenen I, Geerts H, Mercken M, Sciot R, Van Lommel A, Loos R, Van Leuven F (1999) Prominent axonopathy in the brain and spinal cord of transgenic mice overexpressing four-repeat human tau protein. Am J Pathol 155:2153-2165. https://doi.org/10.1016/s0002-9440(10)65533-2

63. Spittaels K, Van den Haute C, Van Dorpe J, Geerts H, Mercken M, Bruynseels K, Lasrado R, Vandezande K, Laenen I, Boon T, Van Lint J, Vandenheede J, Moechars D, Loos R, Van Leuven F (2000) Glycogen synthase kinase-3beta phosphorylates protein tau and rescues the axonopathy in the central nervous system of human four-repeat tau transgenic mice. J Biol Chem 275:41340-41349. https://doi.org/10.1074/jbc.m006219200

64. Strop P, Bankovich AJ, Hansen KC, Garcia KC, Brunger AT (2004) Structure of a human A-type potassium channel interacting protein DPPX, a member of the dipeptidyl aminopeptidase family. J Mol Biol 343:1055-1065. https://doi.org/10.1016/j.jmb.2004.09.003

65. Sun W, Maffie JK, Lin L, Petralia RS, Rudy B, Hoffman DA (2011) DPP6 establishes the A-type $\mathrm{K}(+)$ current gradient critical for the regulation of dendritic excitability in CA1 hippocampal neurons. Neuron 71:1102-1115

66. Takahashi RH, Almeida CG, Kearney PF, Yu F, Lin MT, Milner TA, Gouras GK (2004) Oligomerization of Alzheimer's beta-amyloid within processes and synapses of cultured neurons and brain. J Neurosci 24:3592-3599. https ://doi.org/10.1523/jneurosci.5167-03.2004

67. Takahashi RH, Capetillo-Zarate E, Lin MT, Milner TA, Gouras GK (2010) Co-occurrence of Alzheimer's disease ss-amyloid and tau pathologies at synapses. Neurobiol Aging 31:1145-1152. https://doi.org/10.1016/j.neuro biolaging.2008.07.021

68. Takahashi RH, Capetillo-Zarate E, Lin MT, Milner TA, Gouras GK (2013) Accumulation of intraneuronal beta-amyloid 42 peptides is associated with early changes in microtubule-associated protein 2 in neurites and synapses. PLoS One 8:e51965. https://doi.org/10.1371/journ al.pone.0051965

69. Terry RD, Gonatas NK, Weiss M (1964) Ultrastructural studies in Alzheimer's presenile dementia. Am J Pathol 44:269-297

70. Terwel D, Lasrado R, Snauwaert J, Vandeweert E, Van Haesendonck C, Borghgraef P, Van Leuven F (2005) Changed conformation of mutant Tau-P301L underlies the moribund tauopathy, absent in progressive, nonlethal axonopathy of Tau-4R/2 N transgenic mice. J Biol Chem 280:3963-3973. https://doi.org/10.1074/jbc.m409876200

71. Torroja L, Packard M, Gorczyca M, White K, Budnik V (1999) The Drosophila beta-amyloid precursor protein homolog promotes synapse differentiation at the neuromuscular junction. J Neurosci 19:7793-7803. https://doi. org/10.1523/jneurosci.19-18-07793.1999

72. Wakabayashi K, Tanji K, Mori F, Takahashi H (2007) The Lewy body in Parkinson's disease: molecules implicated in the formation and degradation 
of alpha-synuclein aggregates. Neuropathology 27:494-506. https://doi. org/10.1111/j.1440-1789.2007.00803.x

73. Wakabayashi KT, H; Obata K and Ikuta F (1992) Immunocytochemical localization of synaptic vesicle-specific protein in Lewy body-containing neurons in Parkinson's disease

74. Wang Z, Yang L, Zheng H (2012) Role of APP and A $B$ in synaptic physiology. Curr Alzheimer Res 9:217-226. https://doi.org/10.2174/1567205127 99361691

75. Weingarten J, Weingarten M, Wegner M, Volknandt W (2017) APP-A novel player within the presynaptic active zone proteome. Front Mol Neurosci 10:43. https://doi.org/10.3389/fnmol.2017.00043

76. Willis M, Leitner I, Jellinger KA, Marksteiner J (2011) Chromogranin peptides in brain diseases. J Neural Transm (Vienna) 118:727-735. https://doi. org/10.1007/s00702-011-0648-Z

77. Zelaya MV, Pérez-Valderrama E, de Morentin XM, Tuñon T, Ferrer I, Luquin MR, Fernandez-Irigoyen J, Santamaría E (2015) Olfactory bulb proteome dynamics during the progression of sporadic Alzheimer's disease: identification of common and distinct olfactory targets across Alzheimer-related co-pathologies. Oncotarget 6:39437-39456. https:// doi.org/10.18632/oncotarget.6254

78. Zhou L, Miller BL, McDaniel CH, Kelly L, J; KO, Miller CA (1998) Frontotemporal Dementia: Neuropil Spheroids and Presynaptic Terminal Degeneration

\section{Publisher's Note}

Springer Nature remains neutral with regard to jurisdictional claims in published maps and institutional affiliations.
Ready to submit your research? Choose BMC and benefit from:

- fast, convenient online submission

- thorough peer review by experienced researchers in your field

- rapid publication on acceptance

- support for research data, including large and complex data types

- gold Open Access which fosters wider collaboration and increased citations

- maximum visibility for your research: over 100M website views per year

At BMC, research is always in progress.

Learn more biomedcentral.com/submissions 